\title{
Close-Ups \\ Gros plans
}

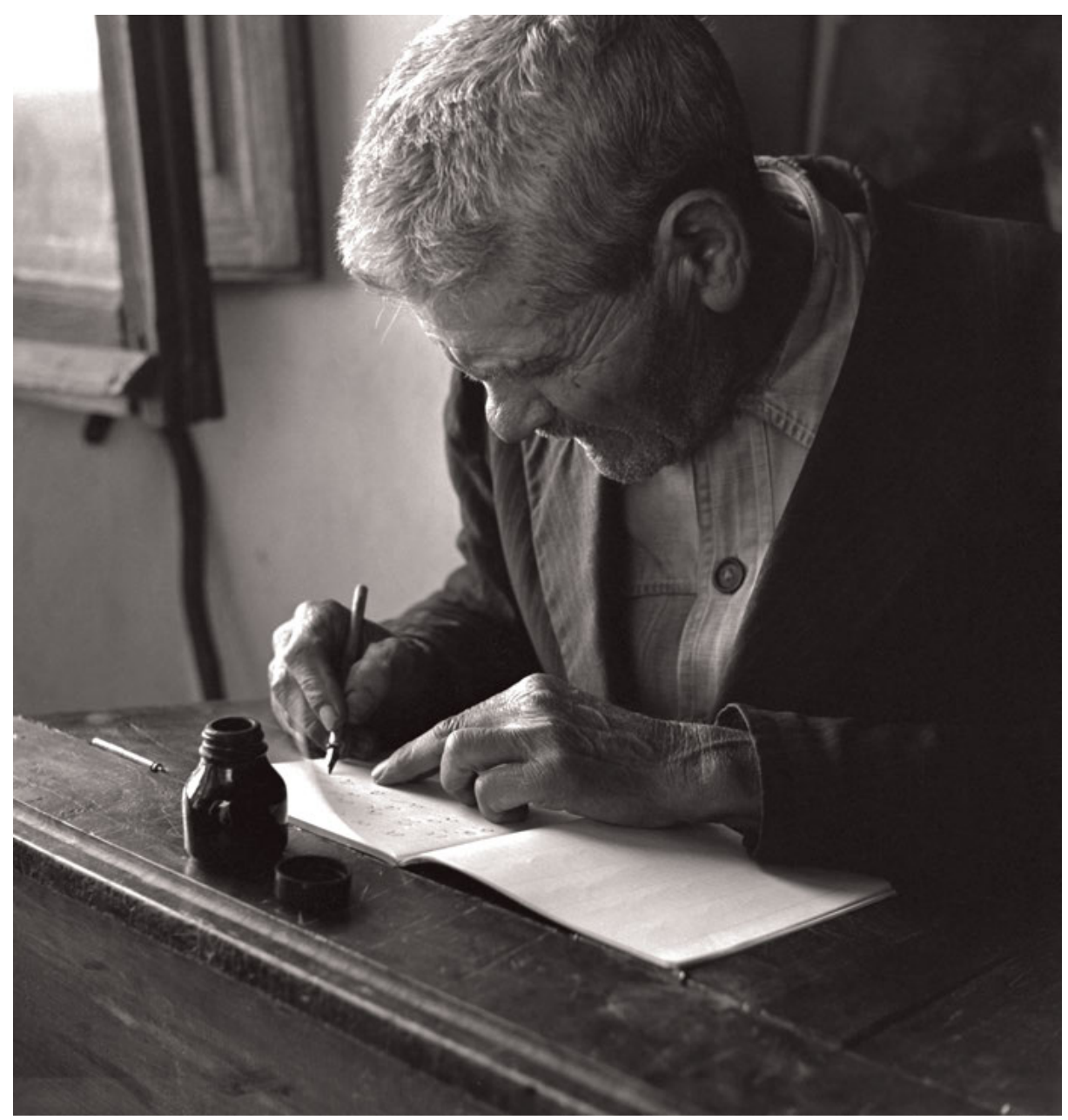

Fig. 1.1

๖ Open Access. () 2019 Giovanna Hendel, Carole Naggar, Karin Priem, published by De Gruyter. (œ) BY-NC-ND This work is licensed under the Creative Commons Attribution-NonCommercial-NoDerivatives 4.0 License. https://doi.org/10.1515/9783110655599-001 


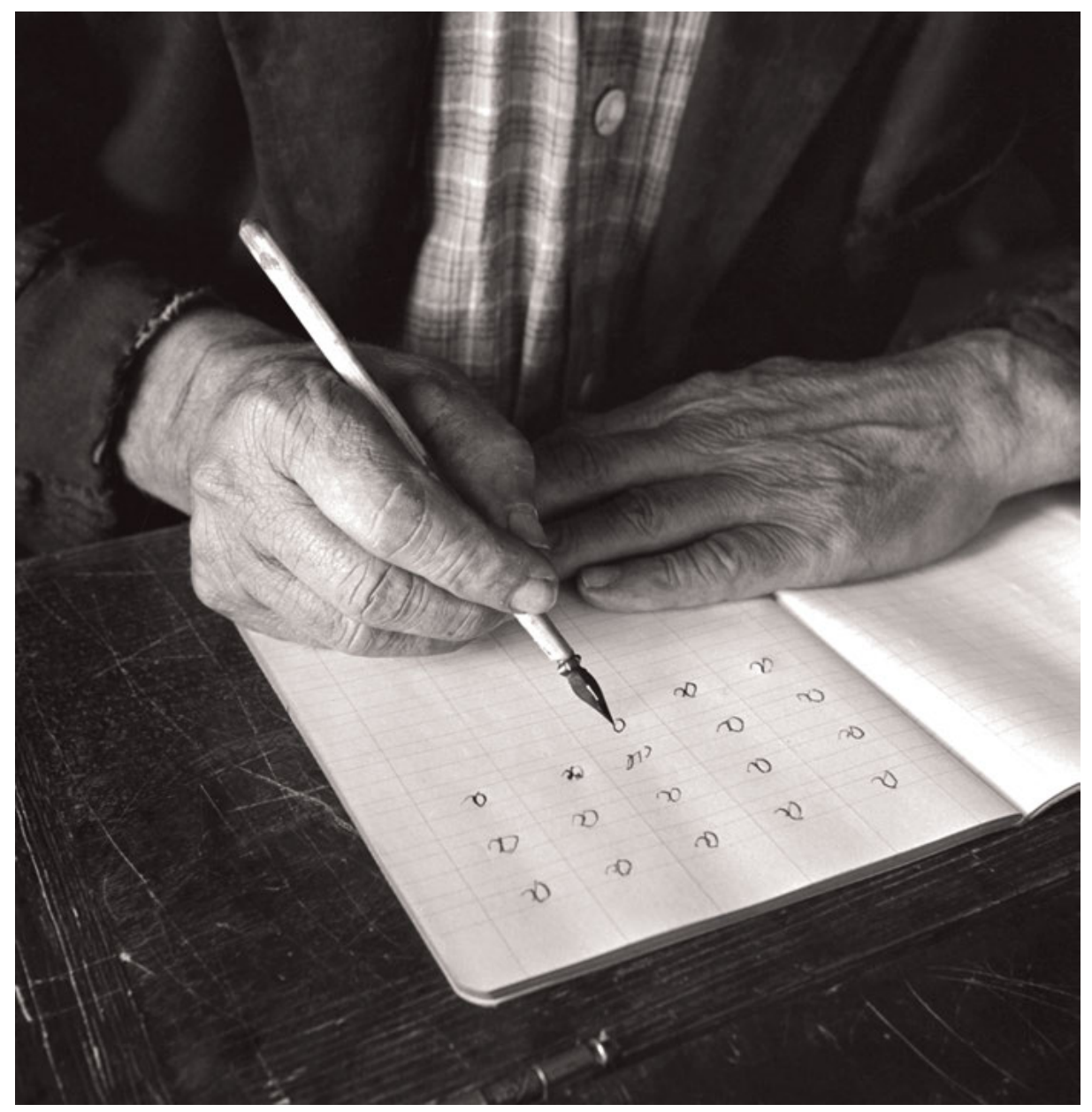

Fig. 1.2 


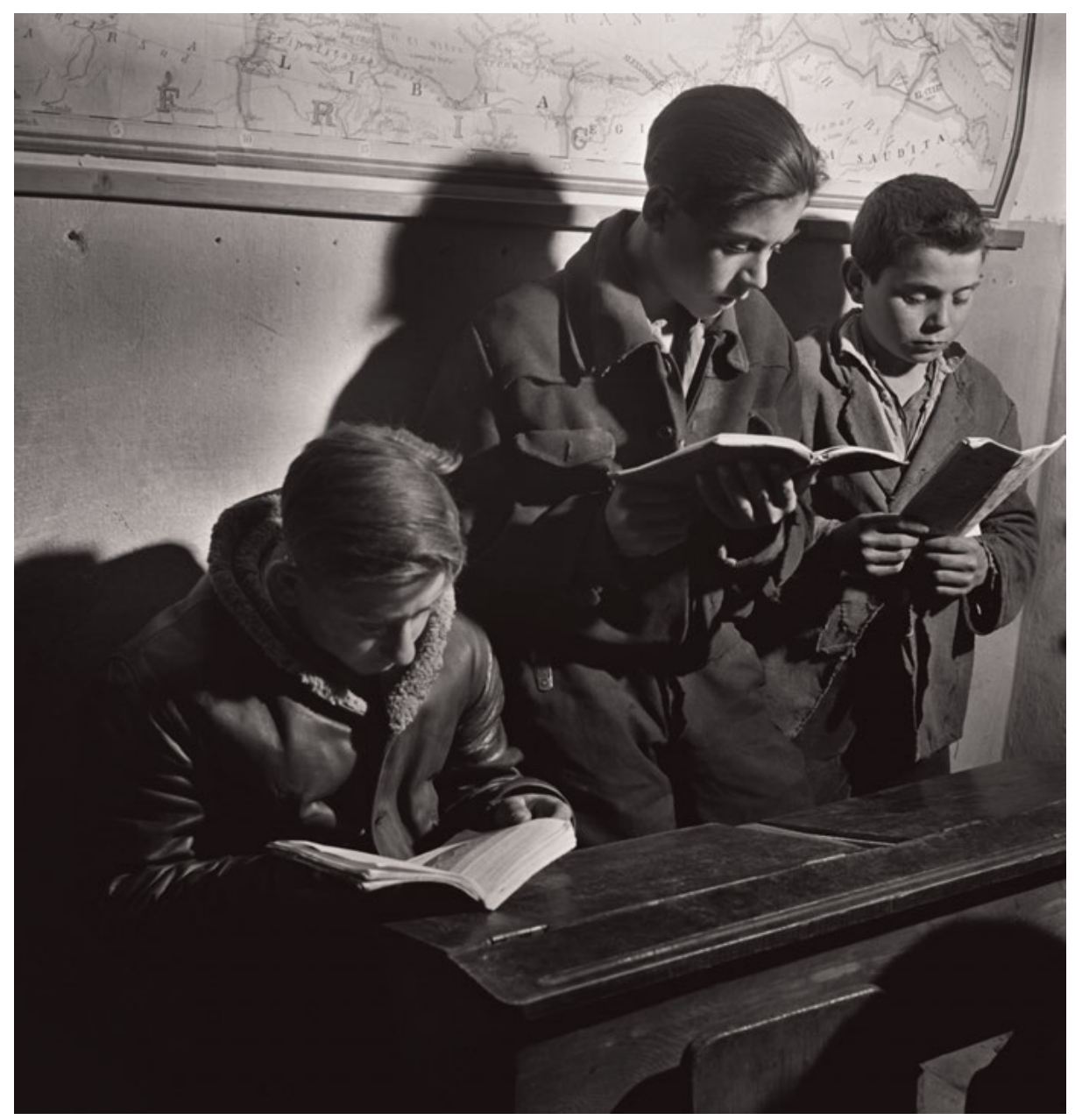

Fig. 1.3 


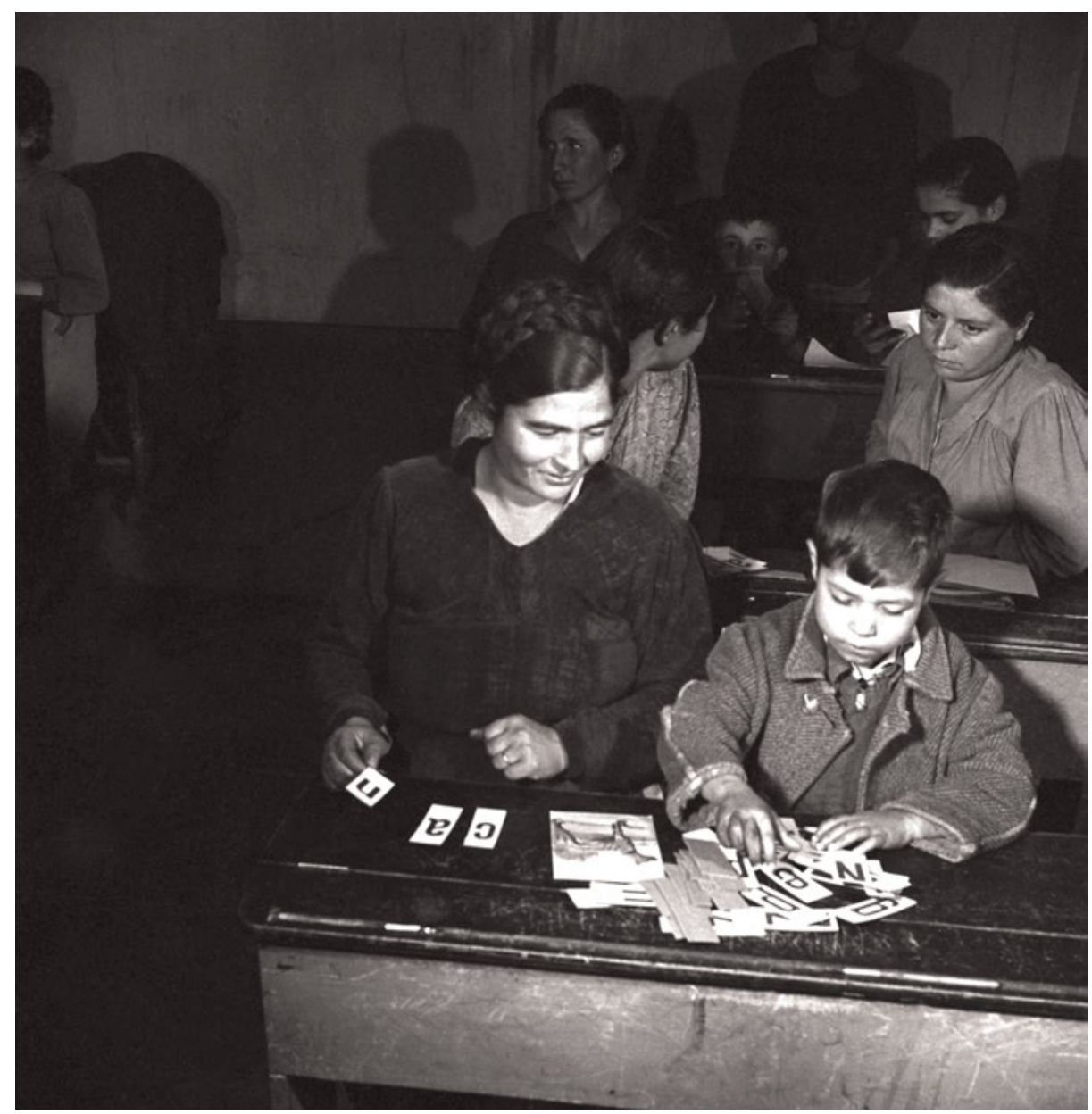

Fig. 1.4 


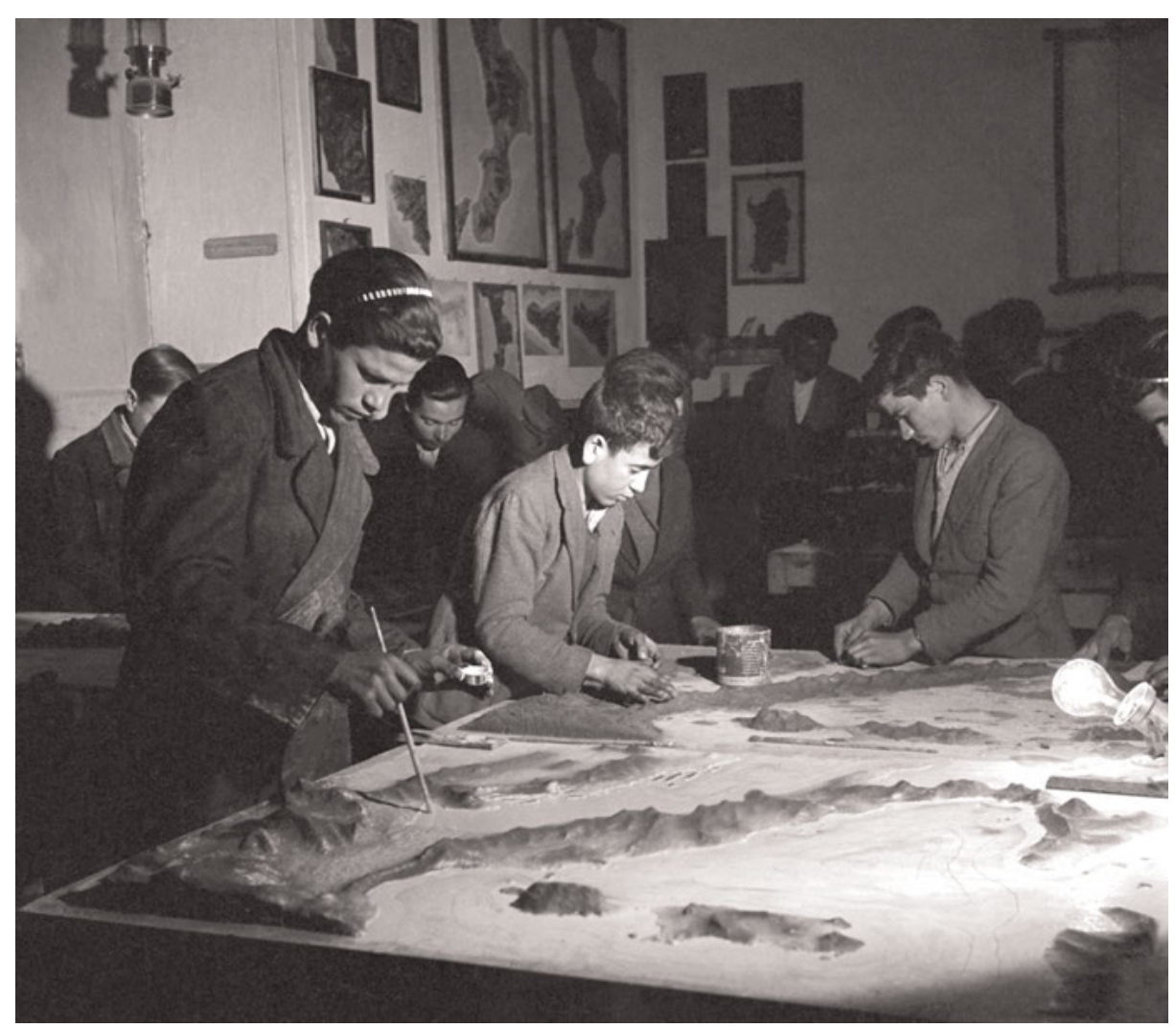

Fig. 1.5 


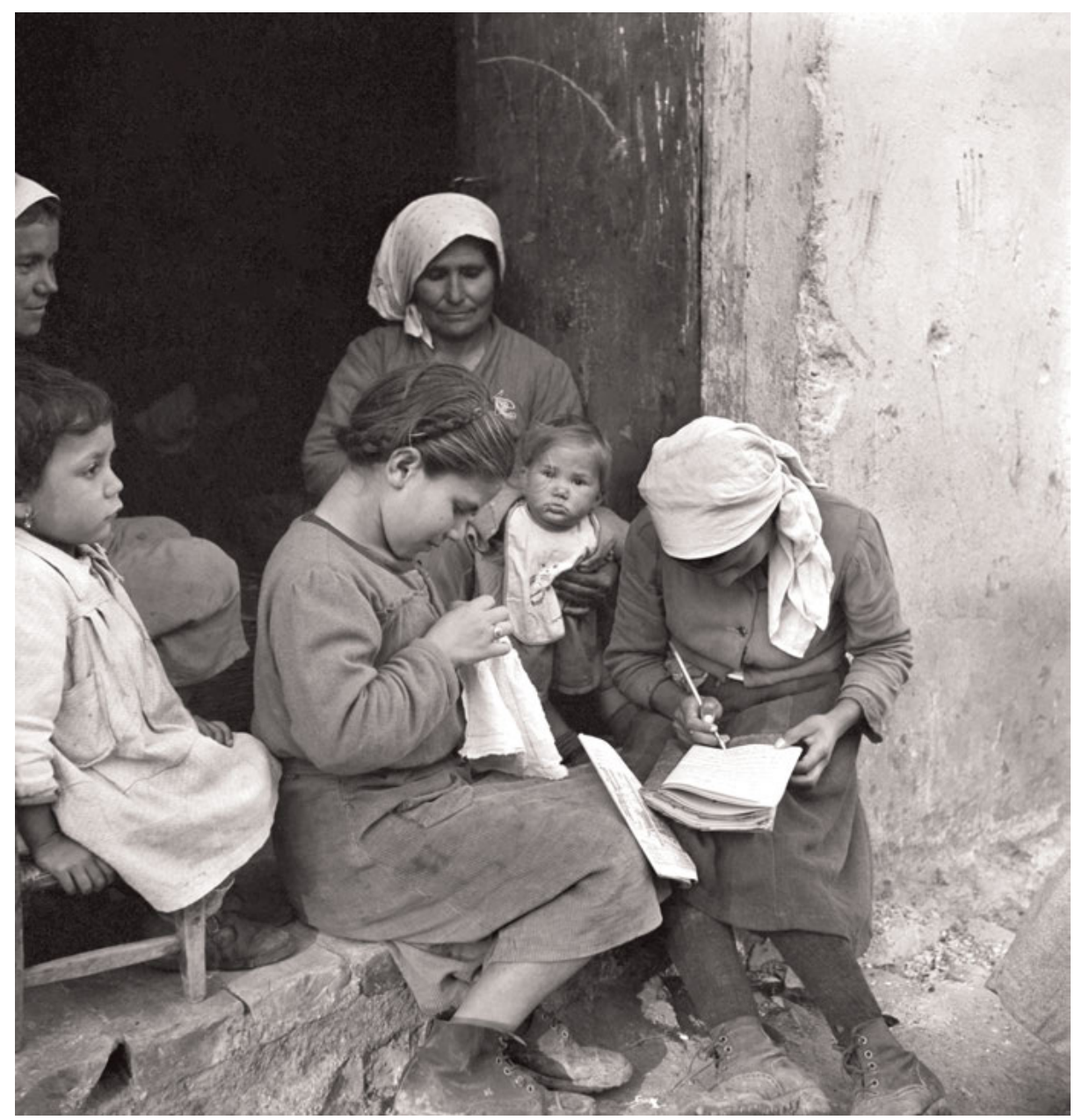

Fig. 1.6 


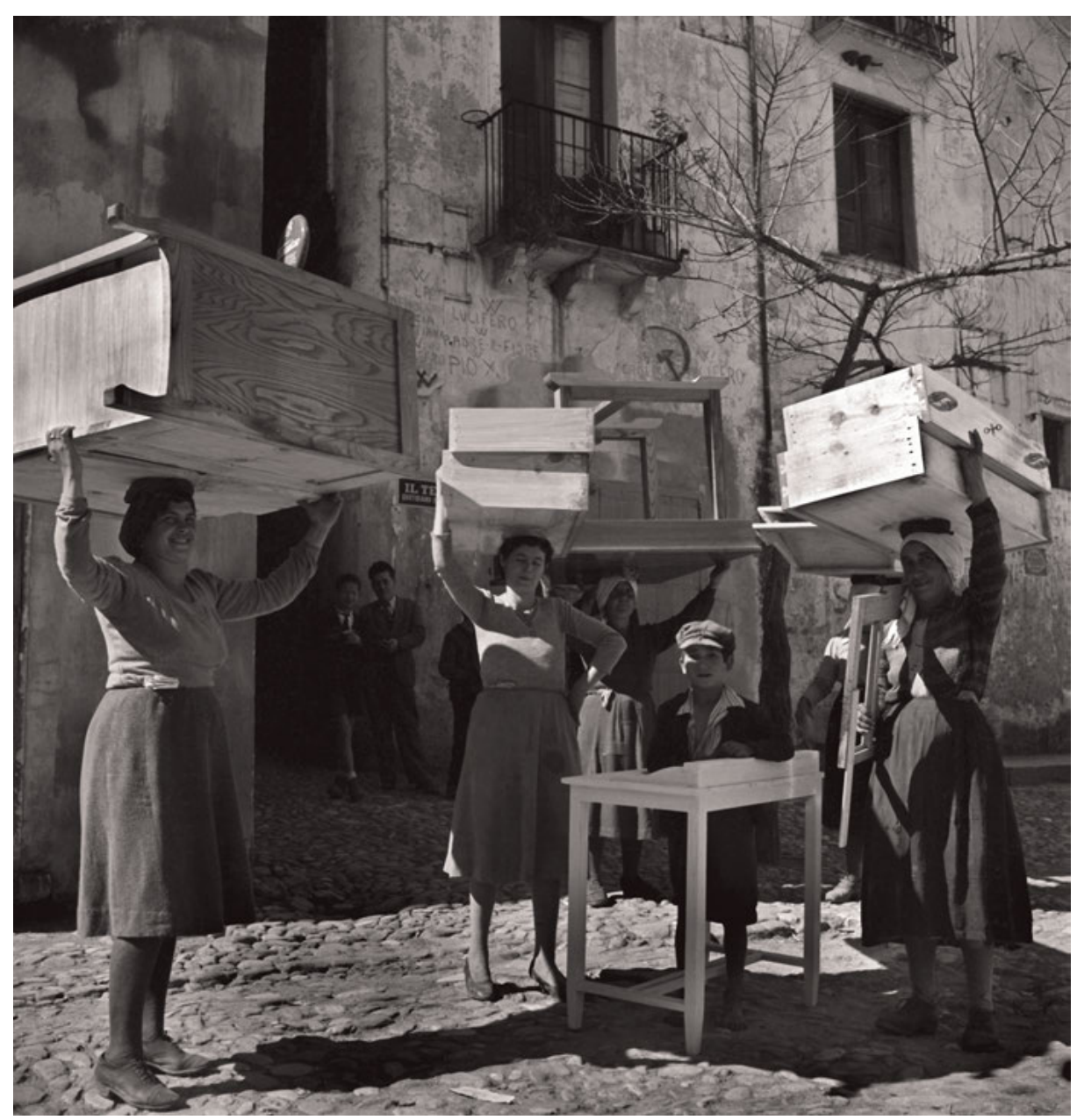

Fig. 1.7 


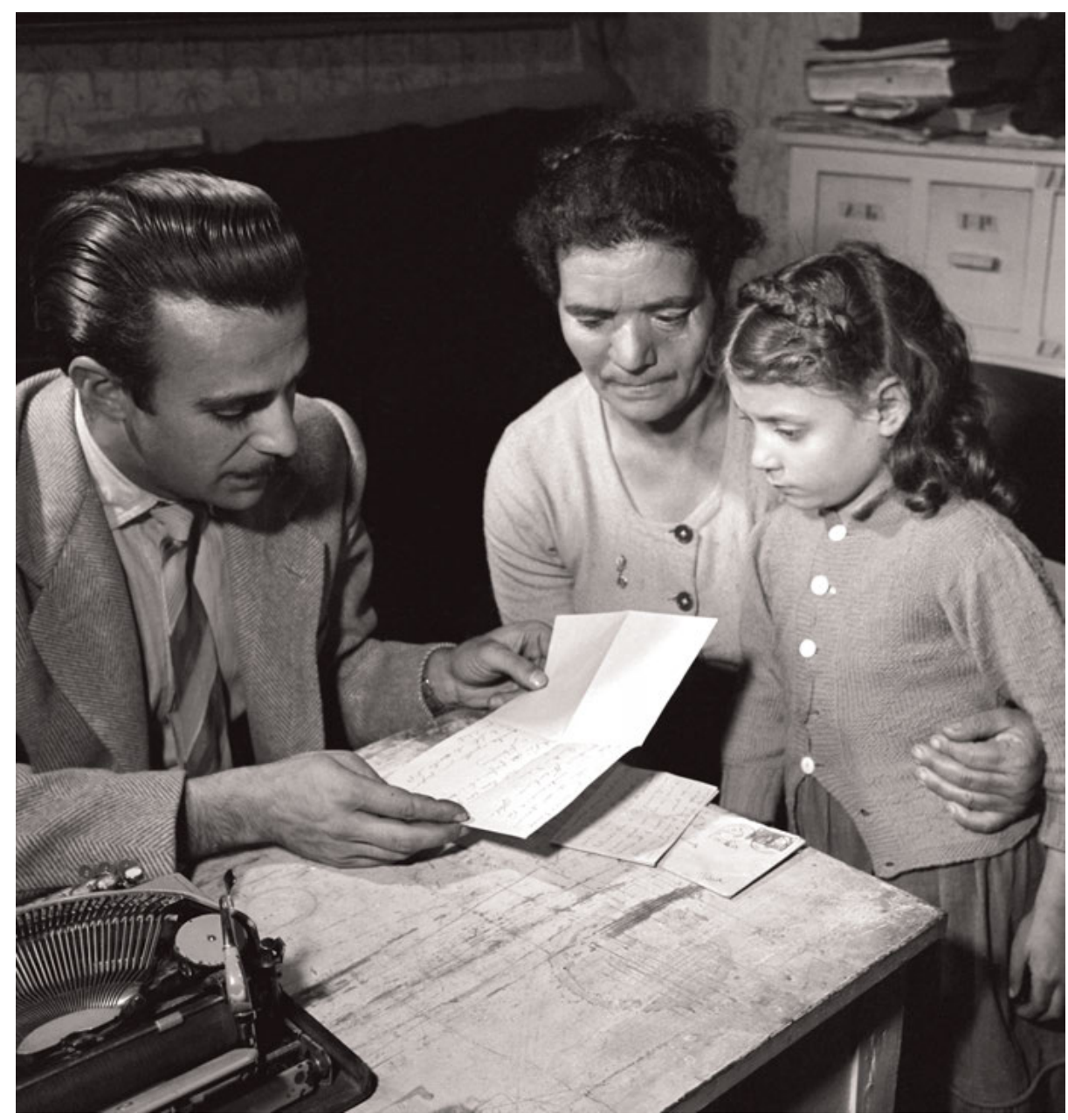

Fig. 1.8 


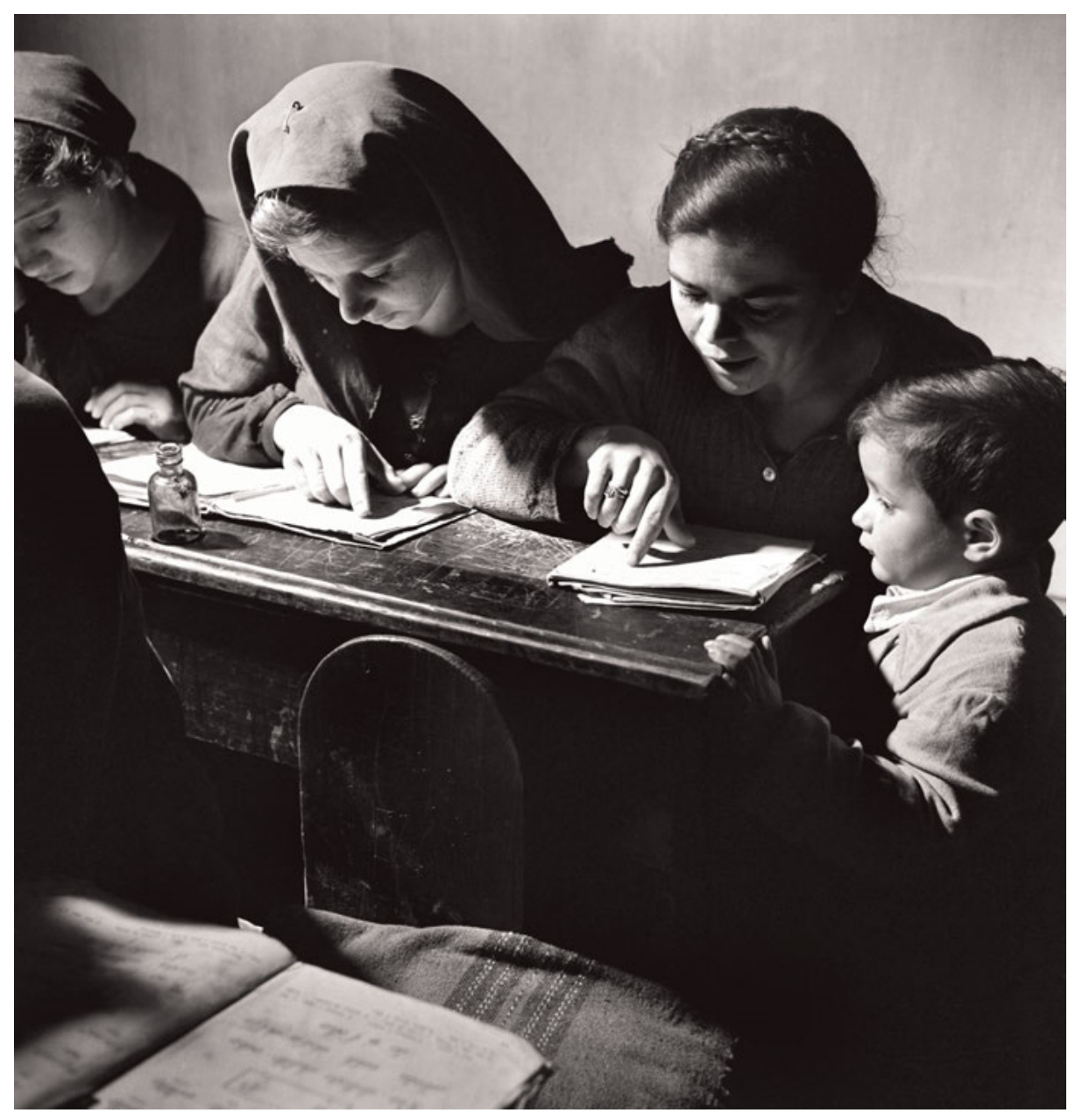

Fig. 1.9 


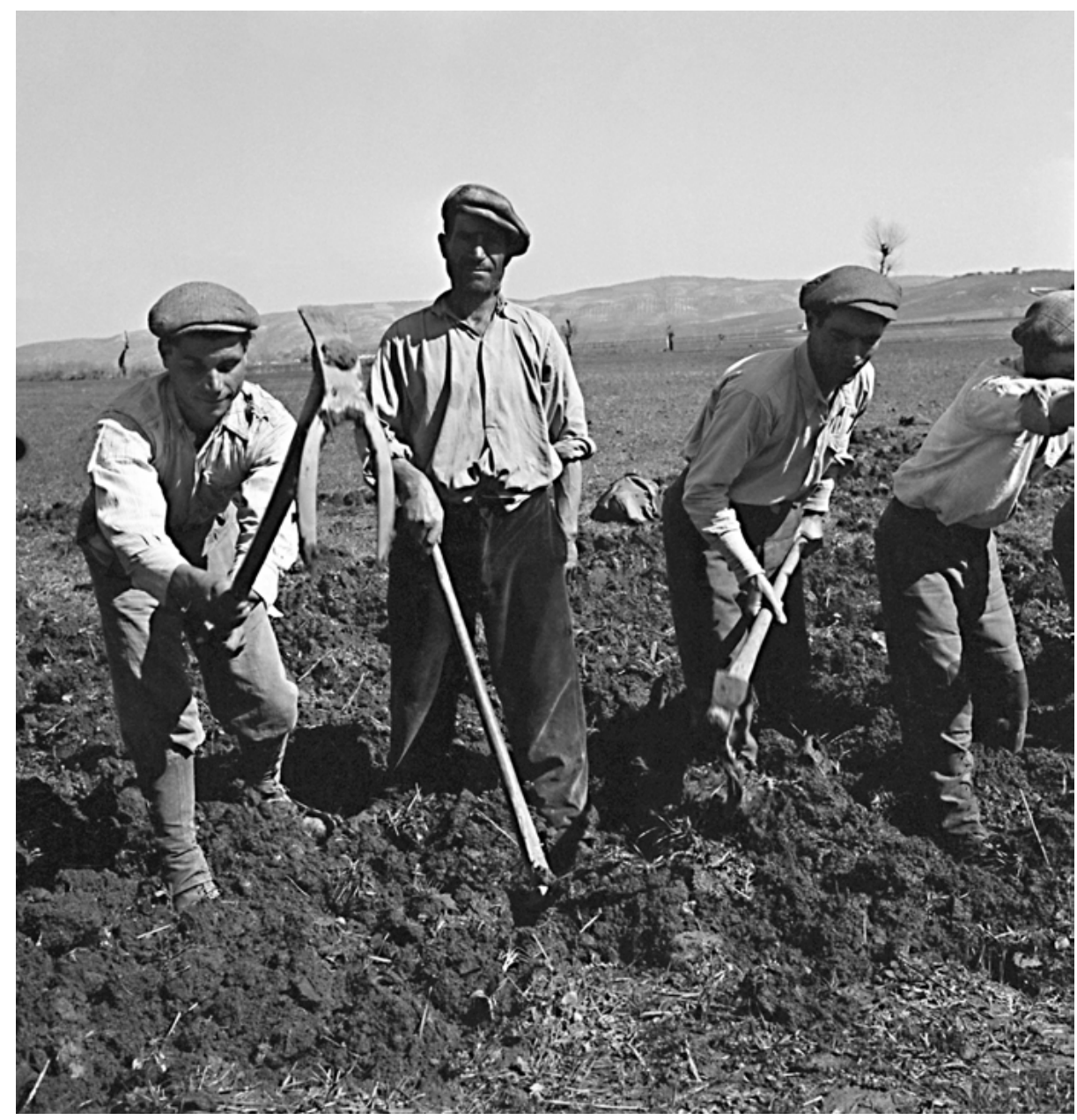

Fig. 1.10 


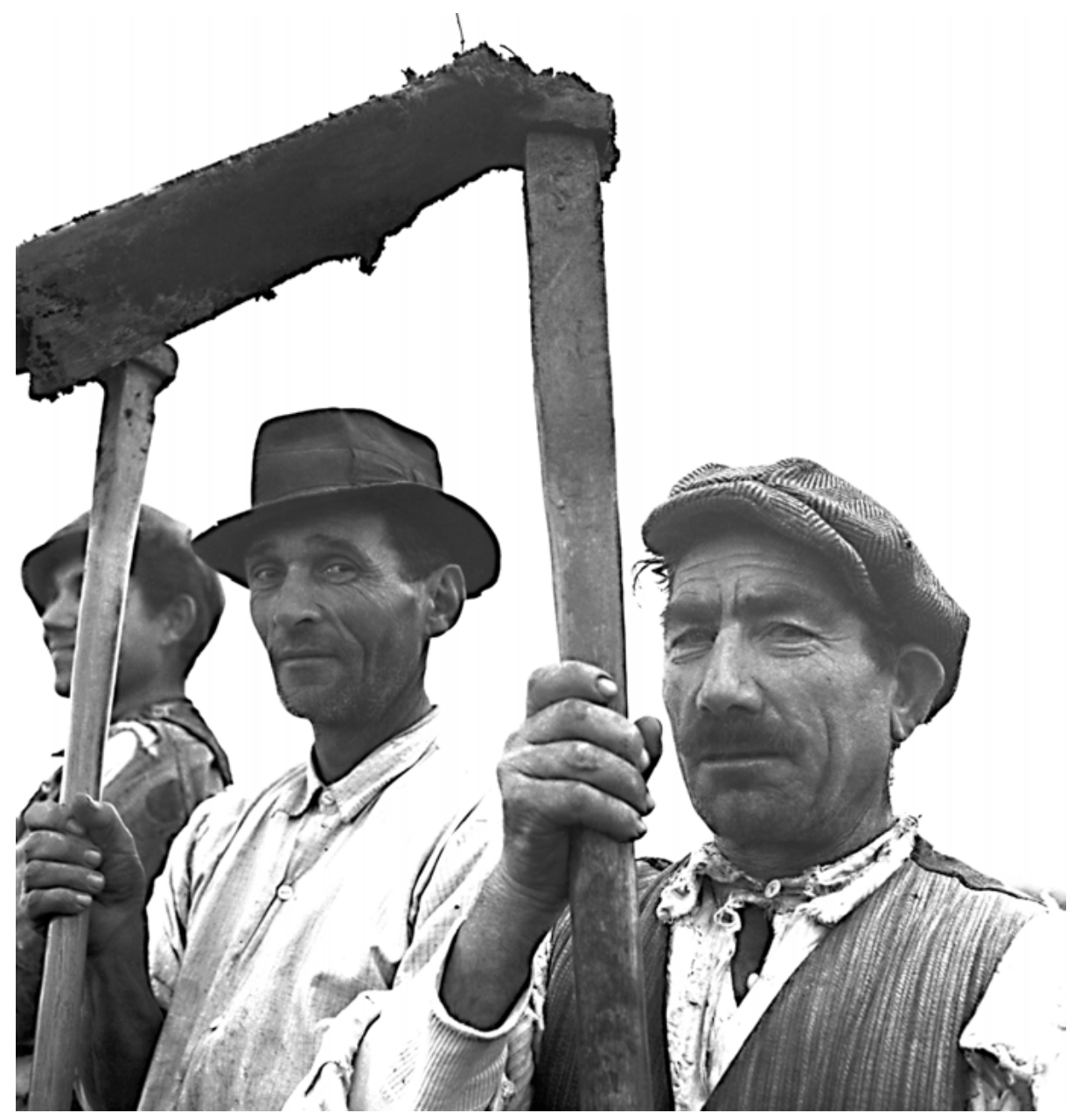

Fig. 1.11 


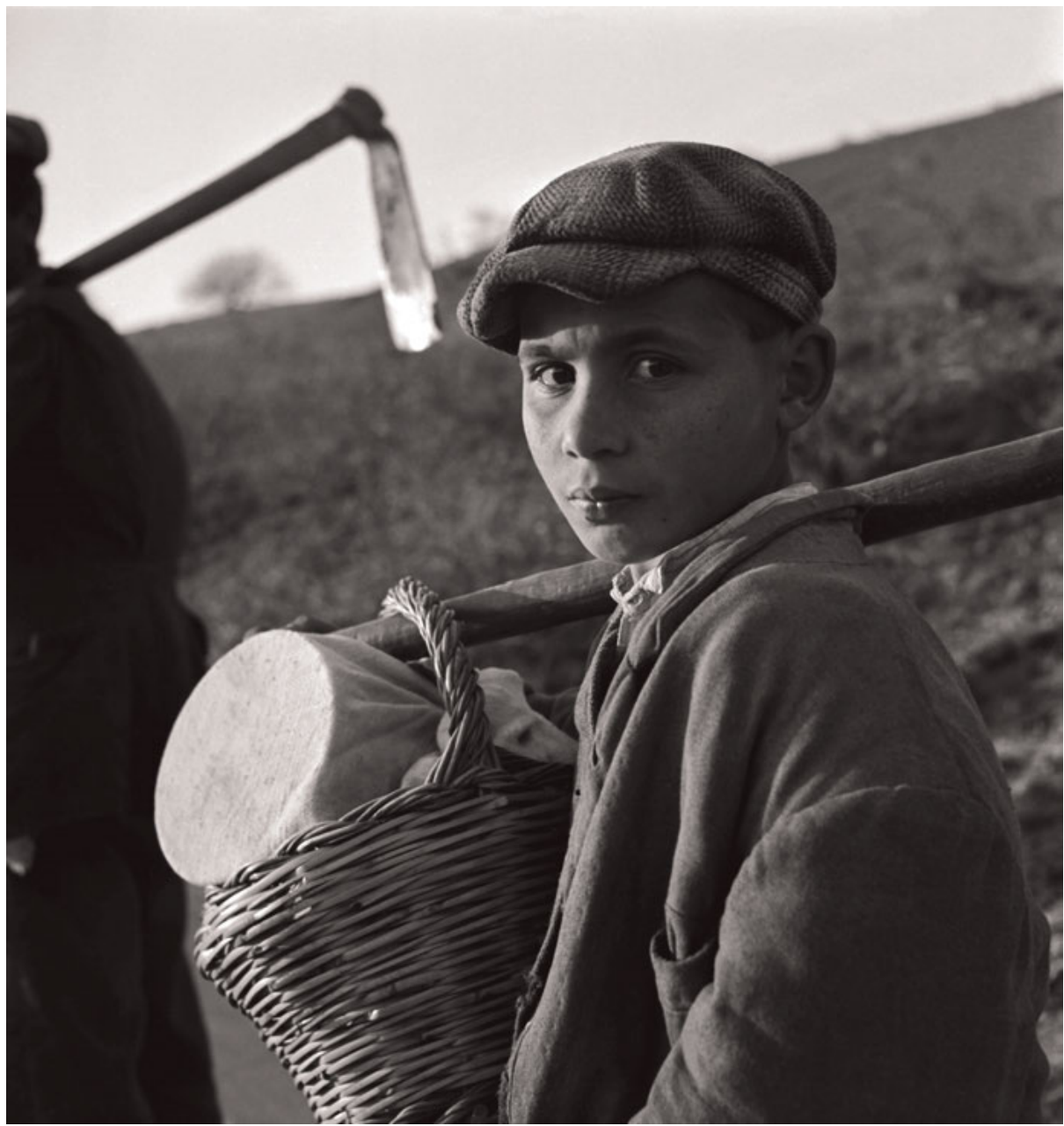

Fig. 1.12 


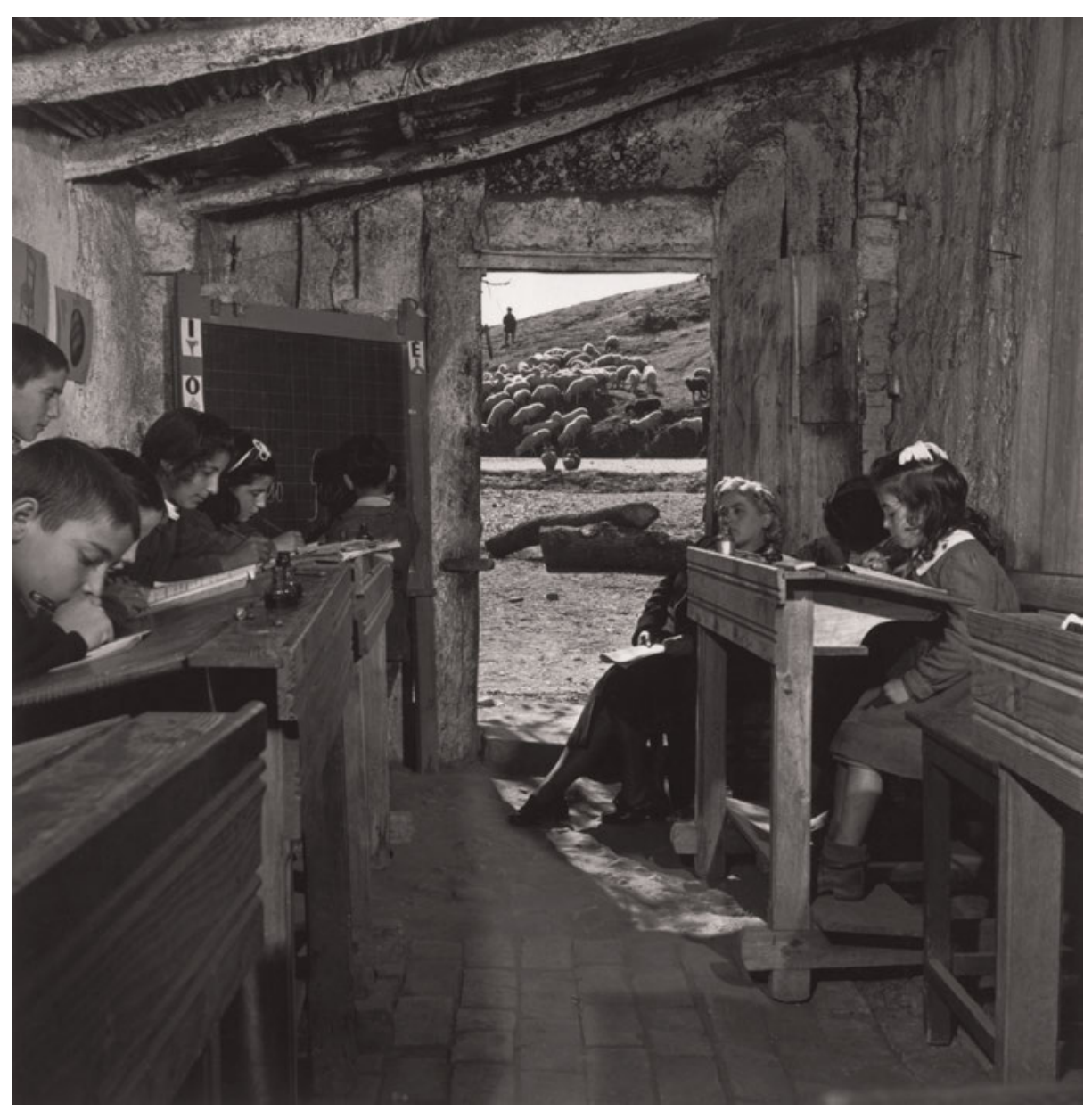

Fig. 1.13 


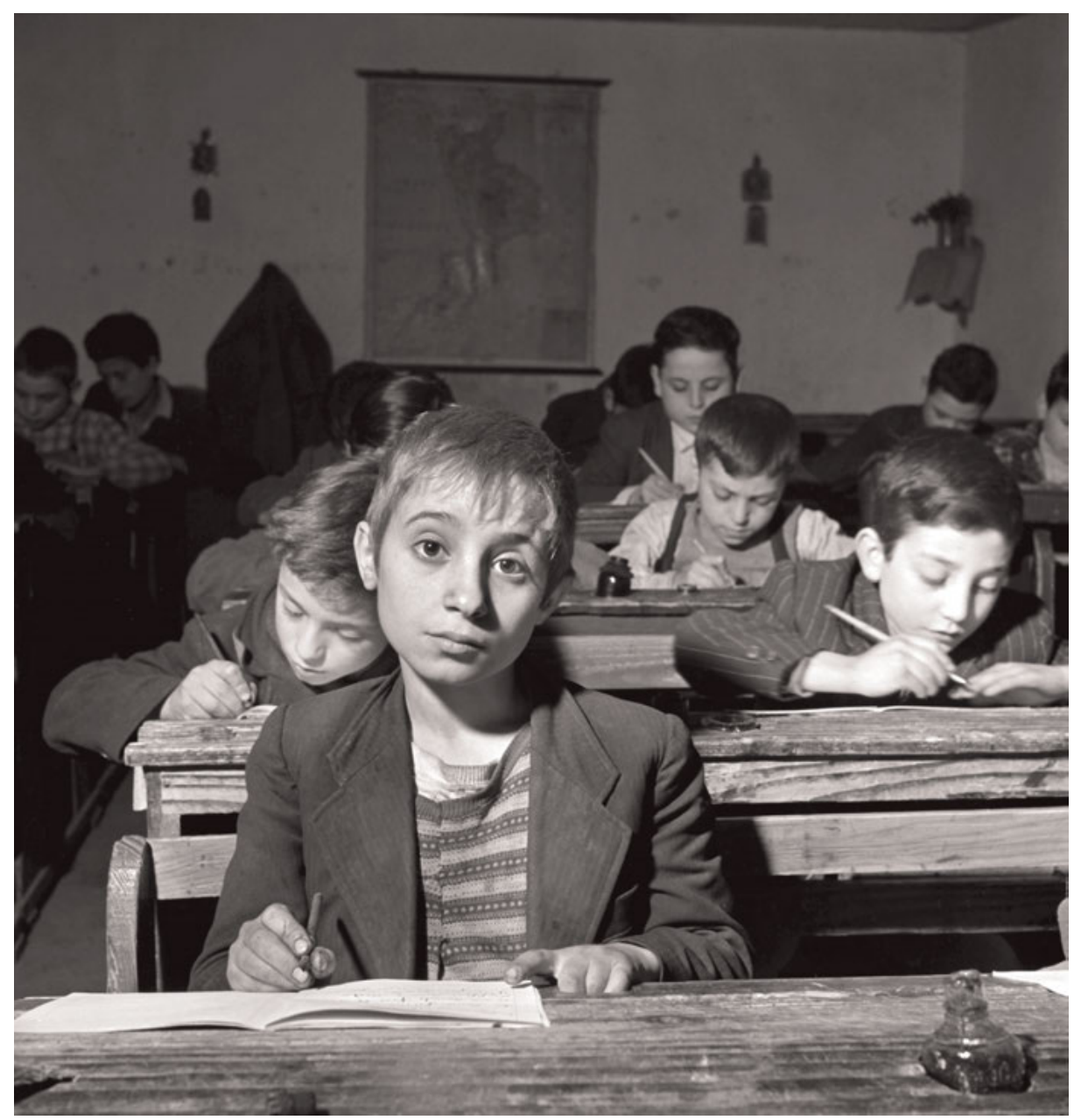

Fig. 1.14 


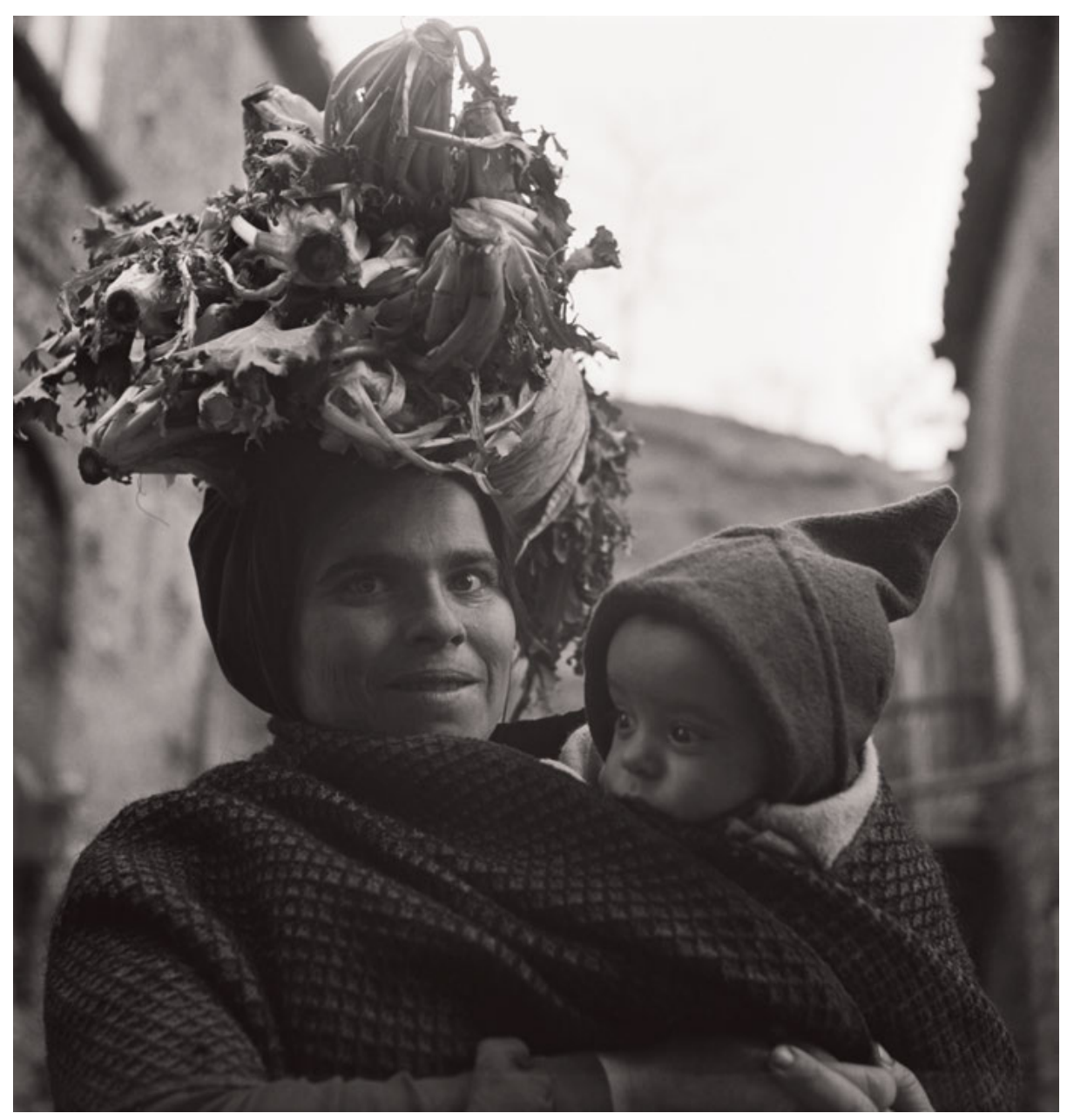

Fig. 1.15 


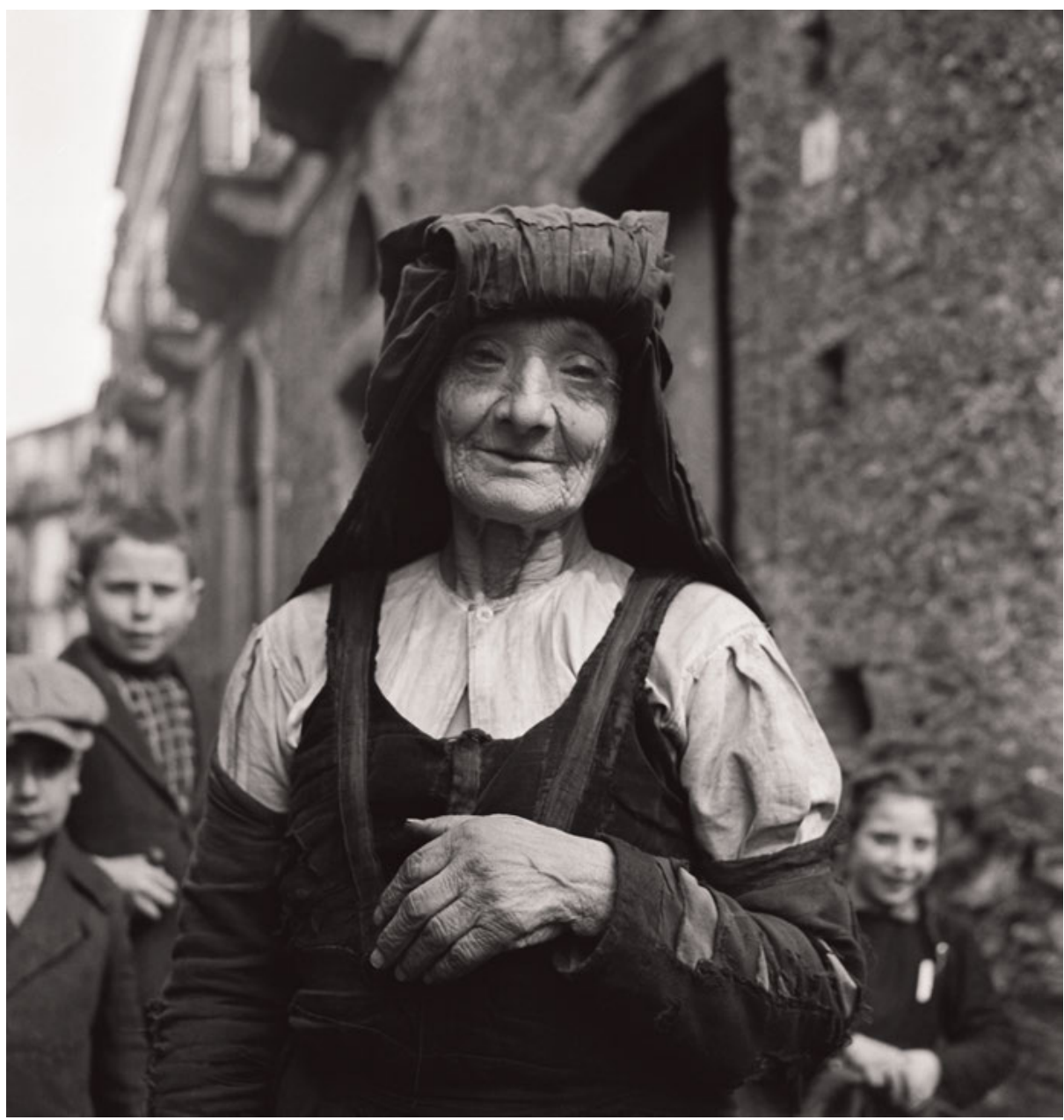

Fig. 1.16 


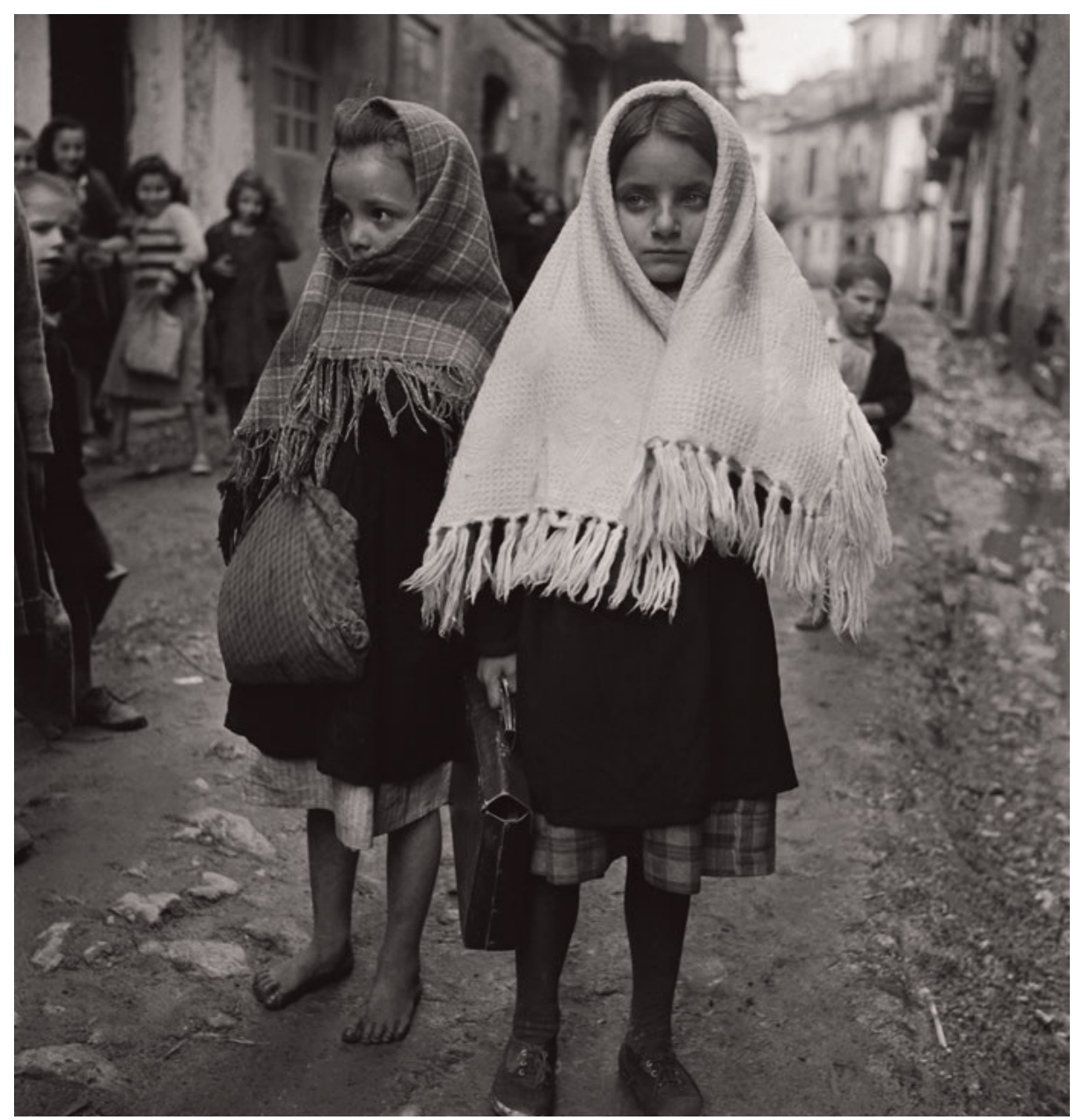

Fig. 1.17 


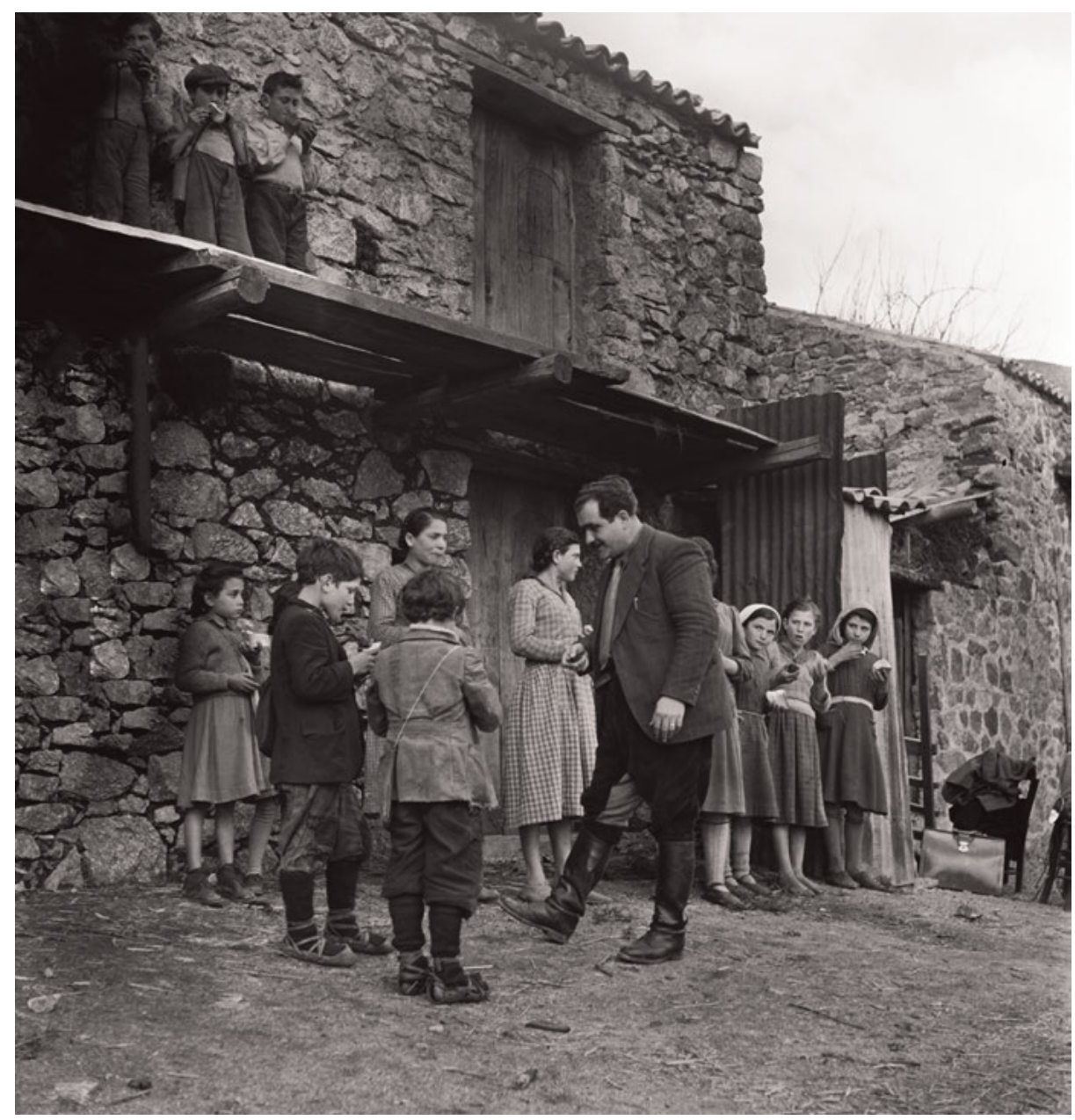

Fig. 1.18 


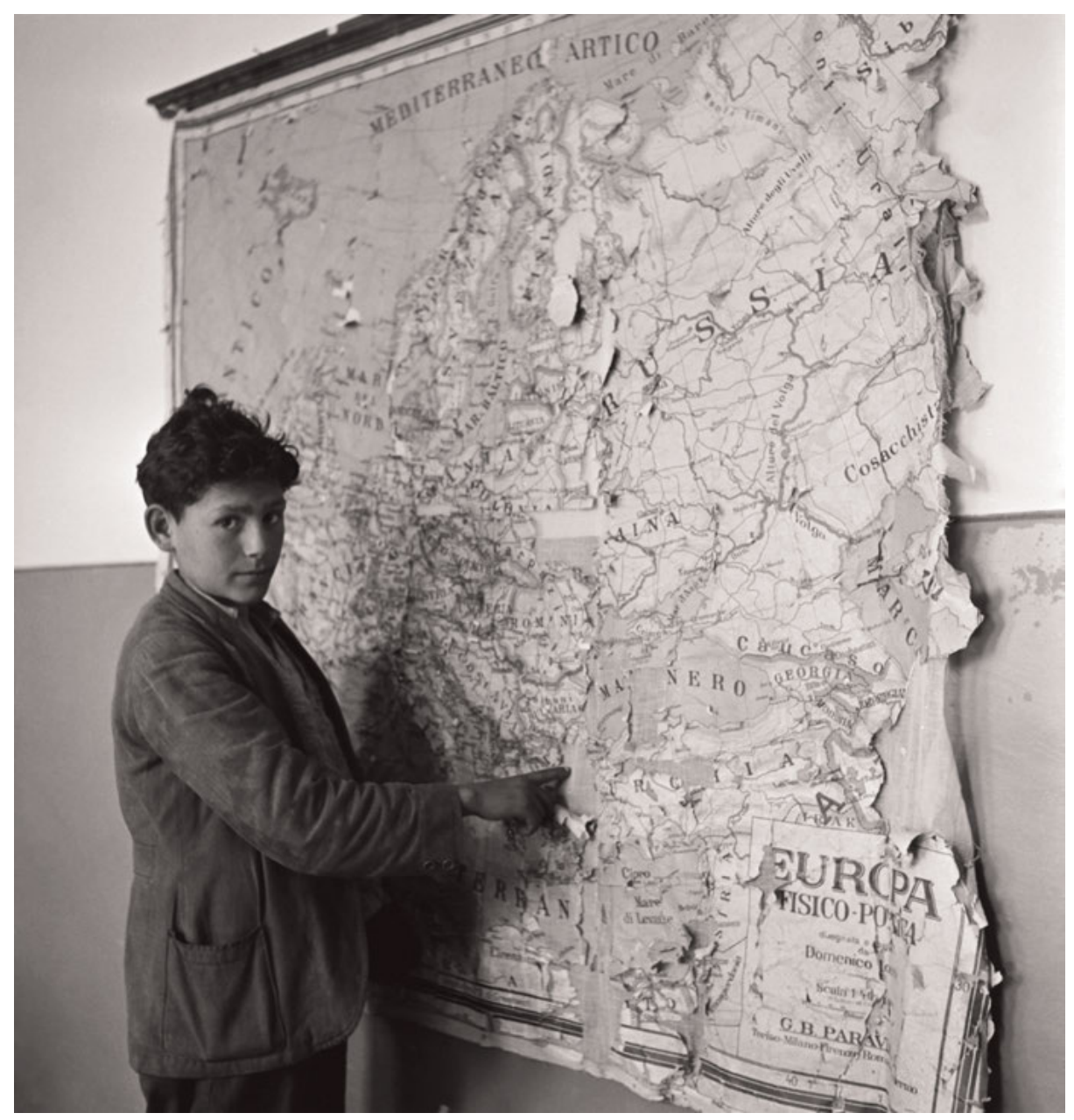

Fig. 1.19 


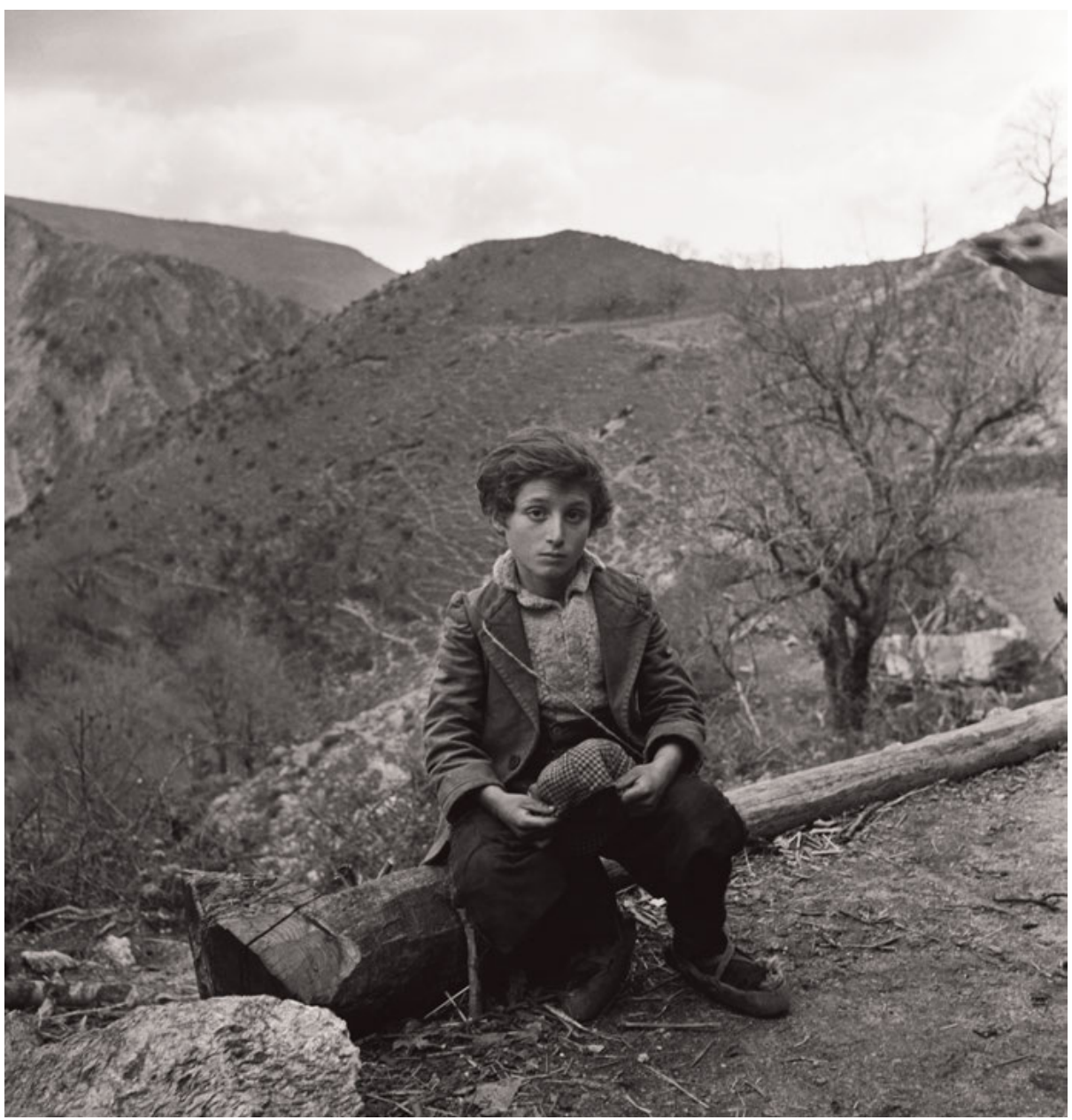

Fig. 1.20 


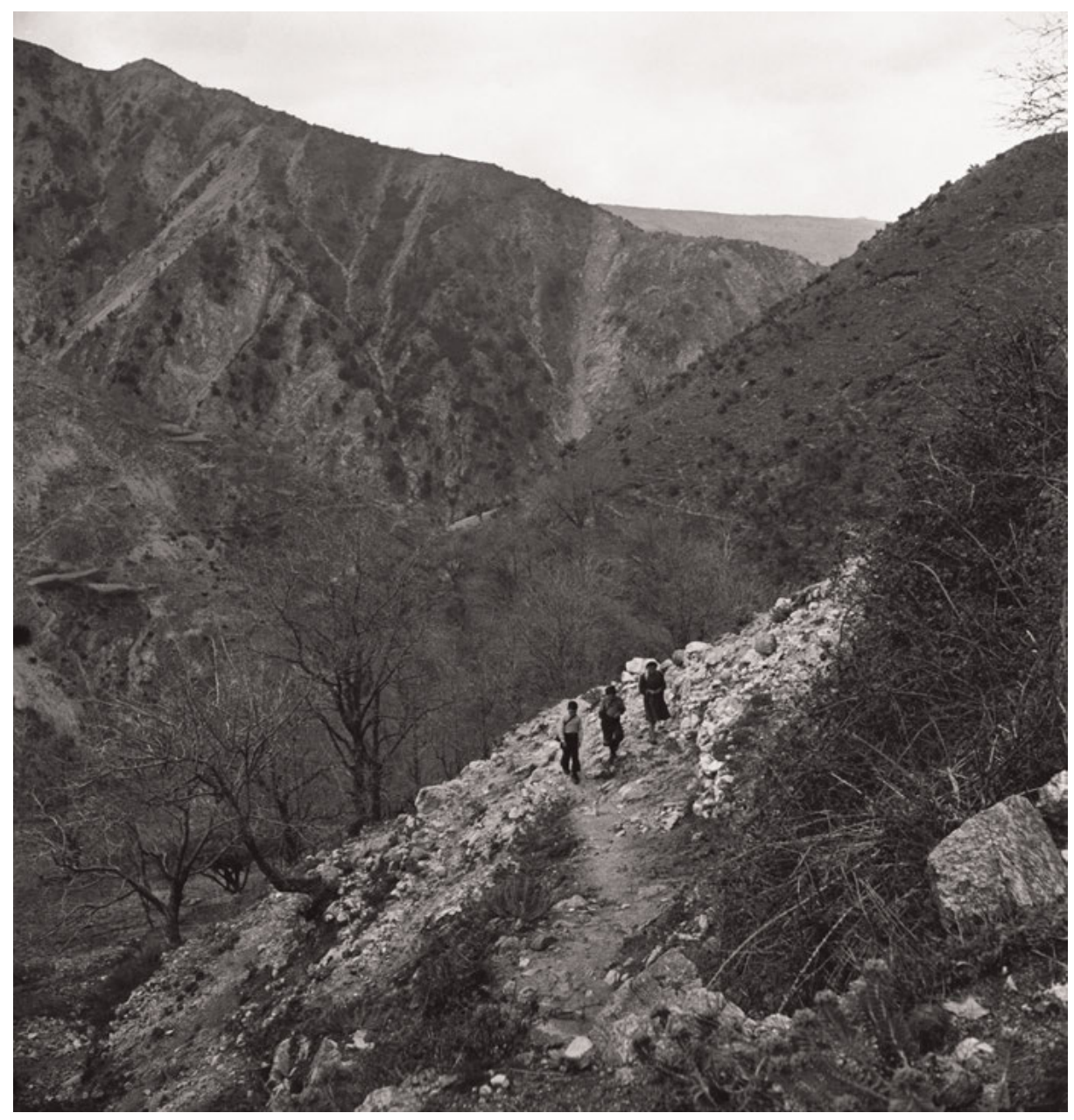

Fig. 1.21 


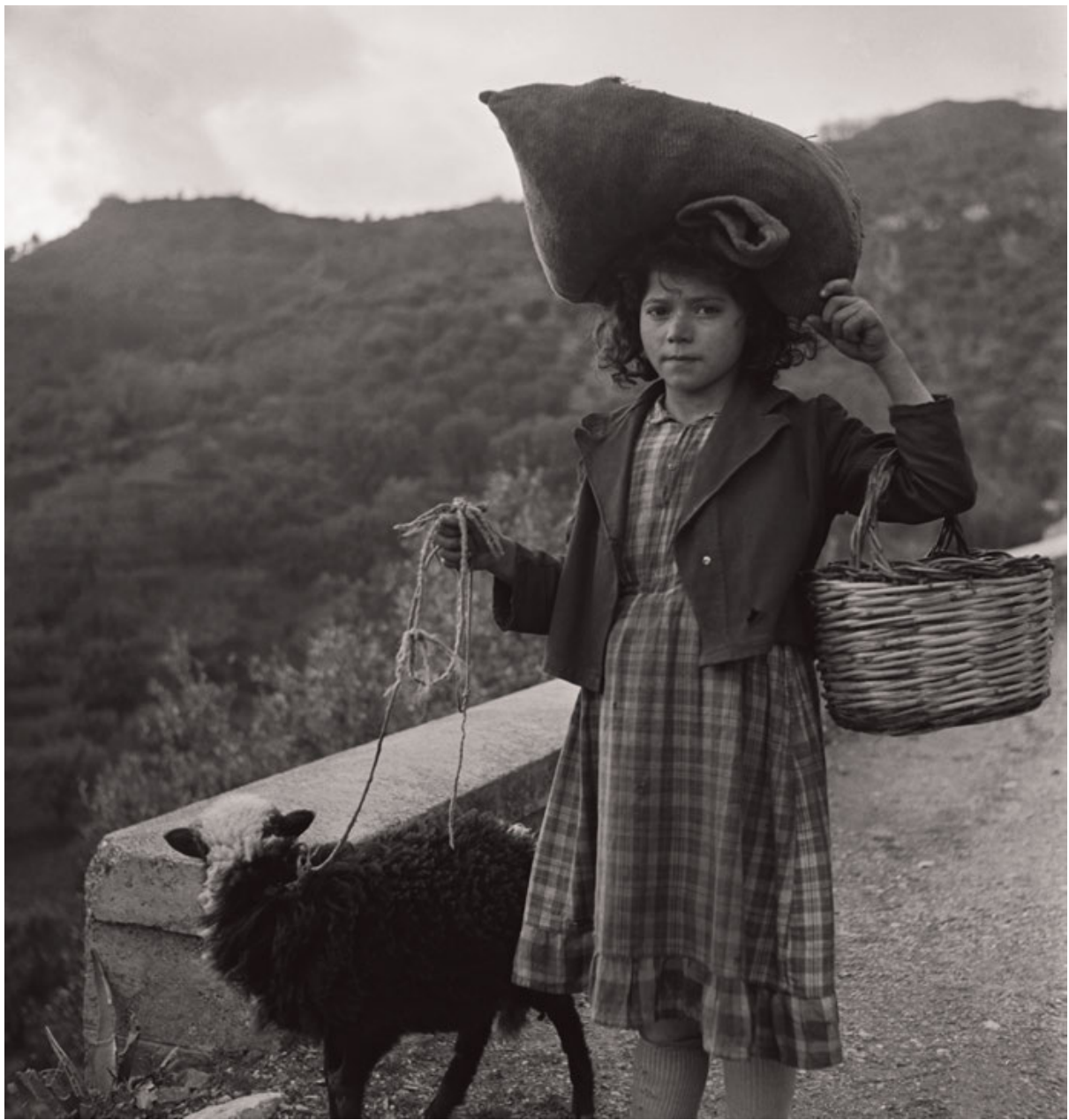

Fig. 1.22 


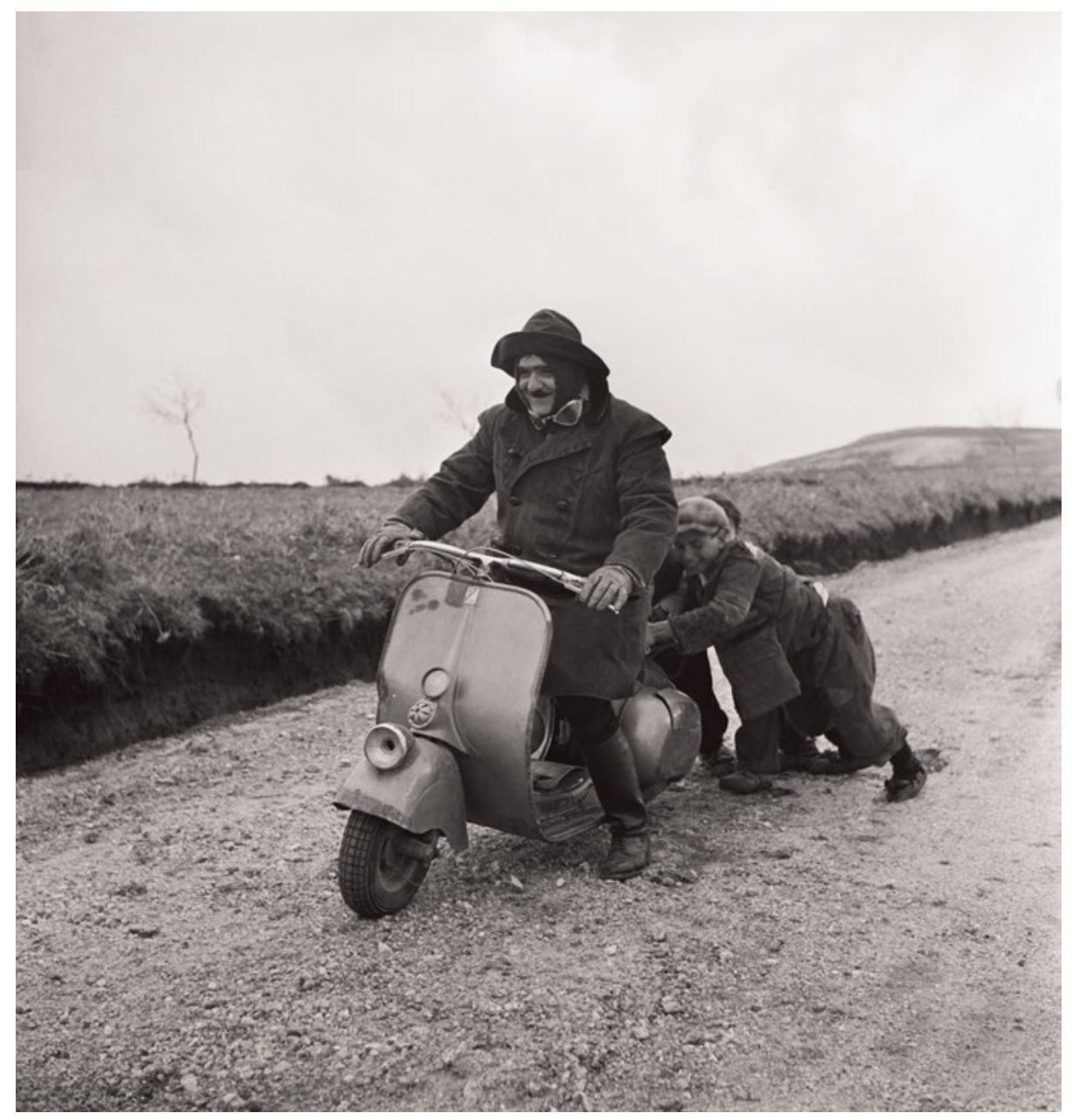

Fig. 1.23 


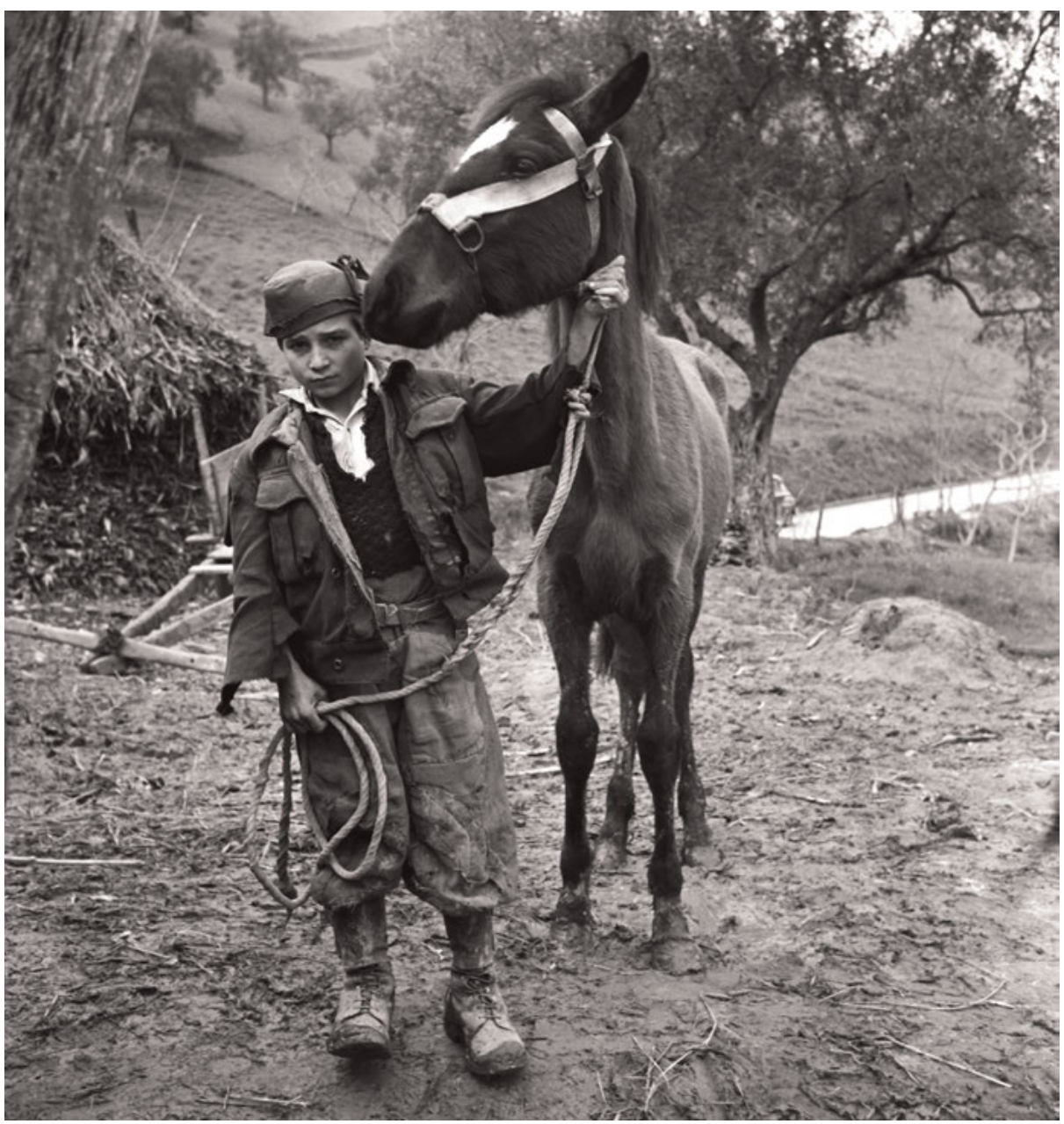

Fig. 1.24 


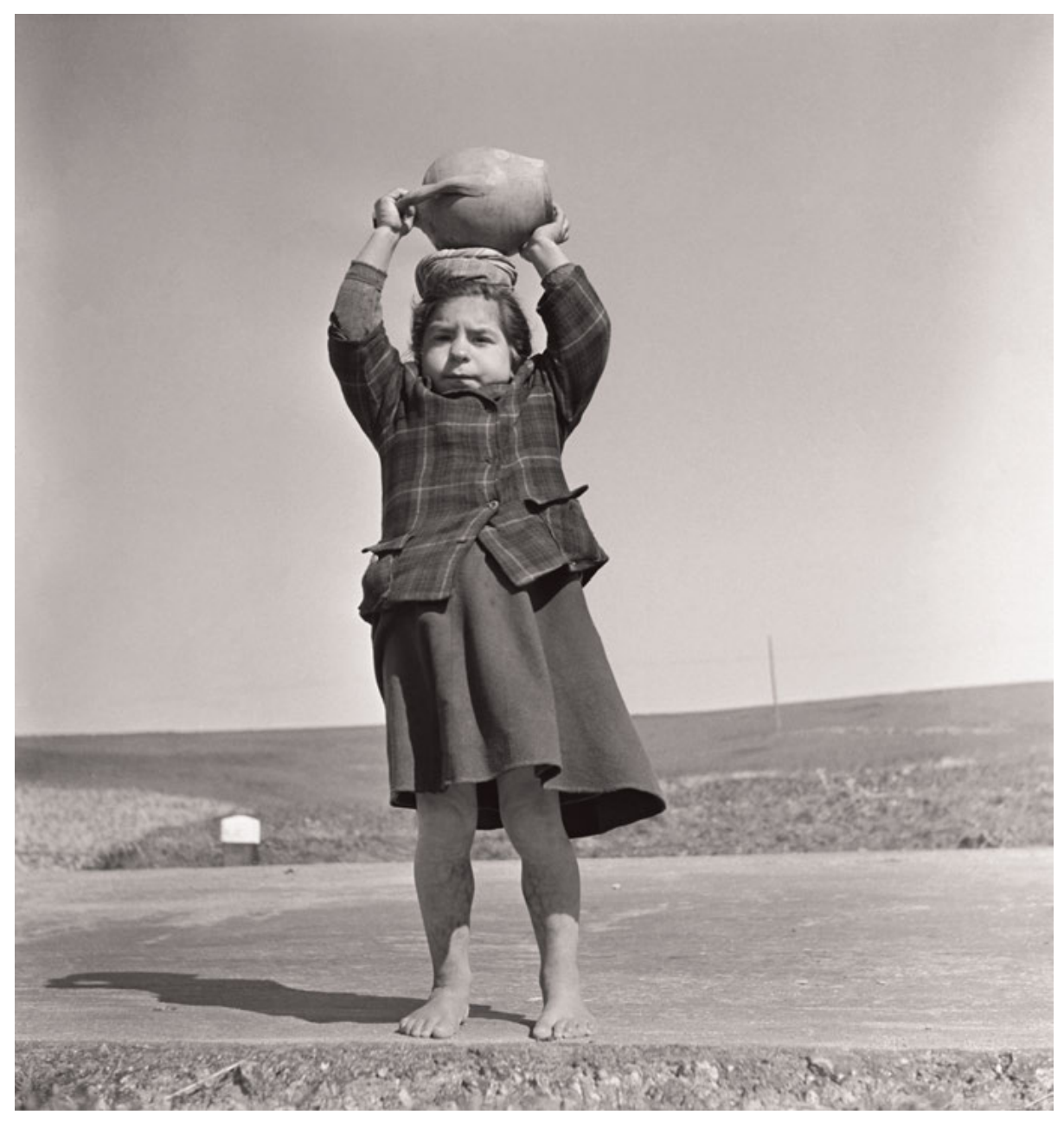

Fig. 1.25 


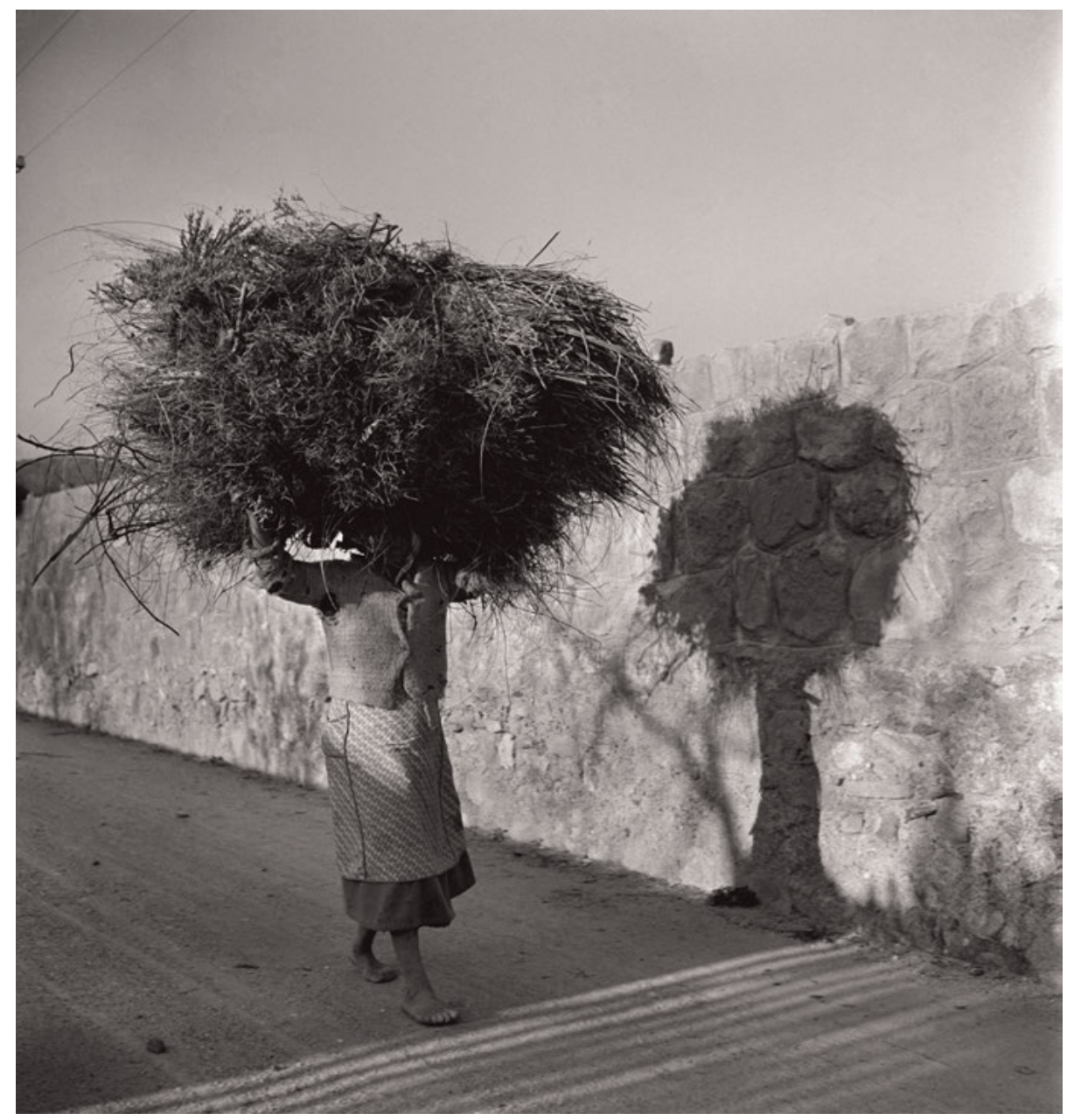

Fig. 1.26 


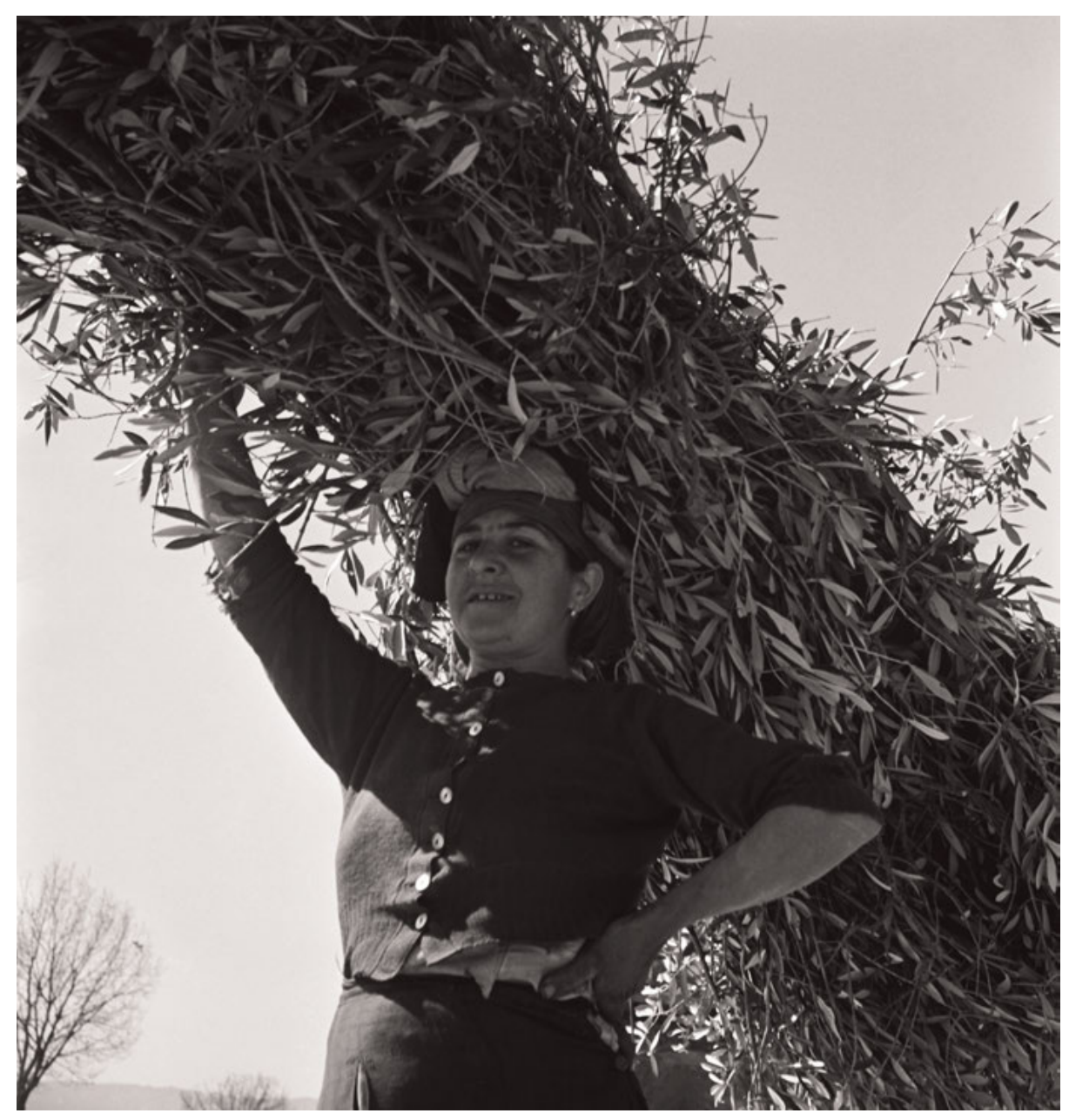

Fig. 1.27 


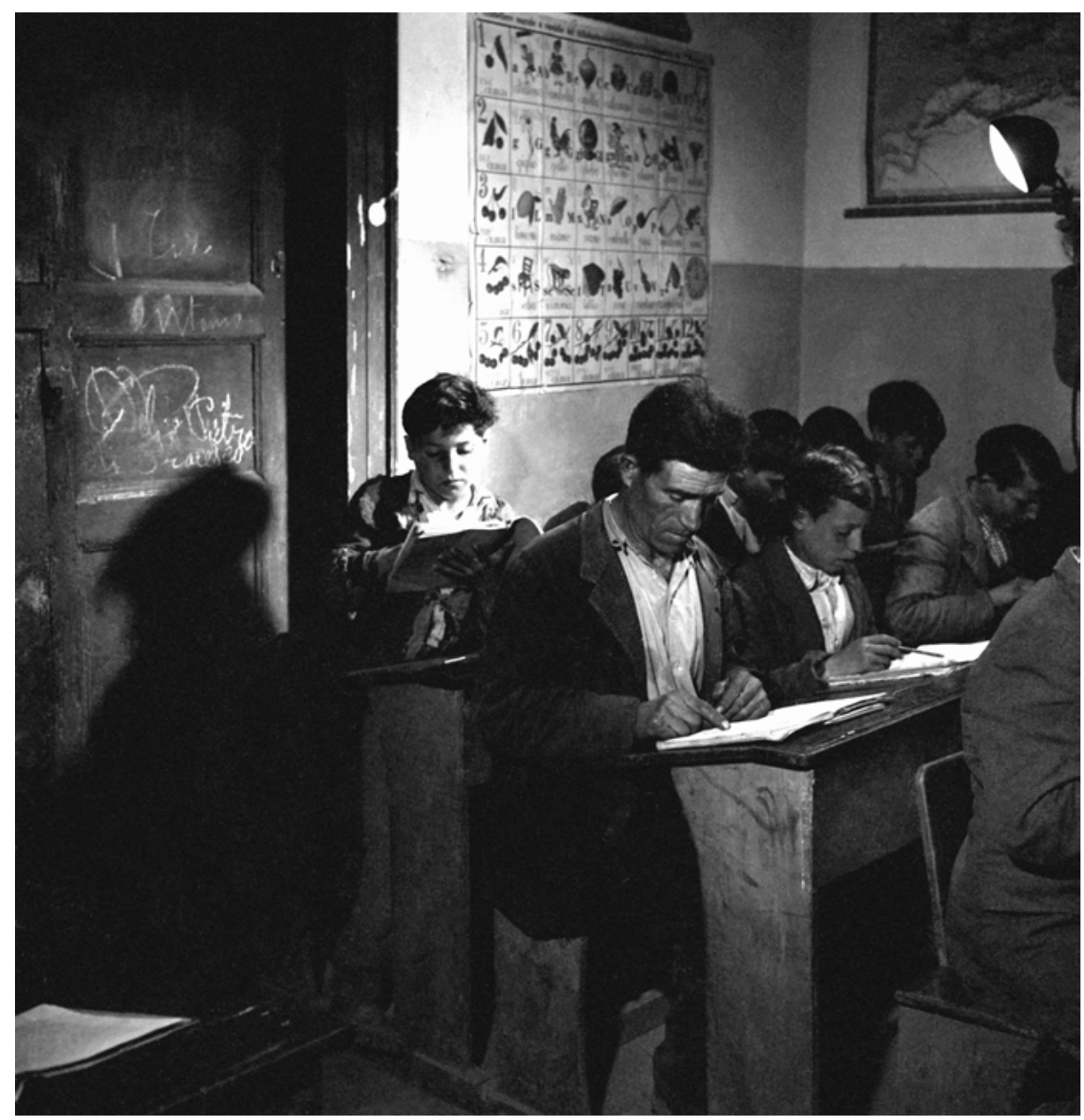

Fig. 1.28 


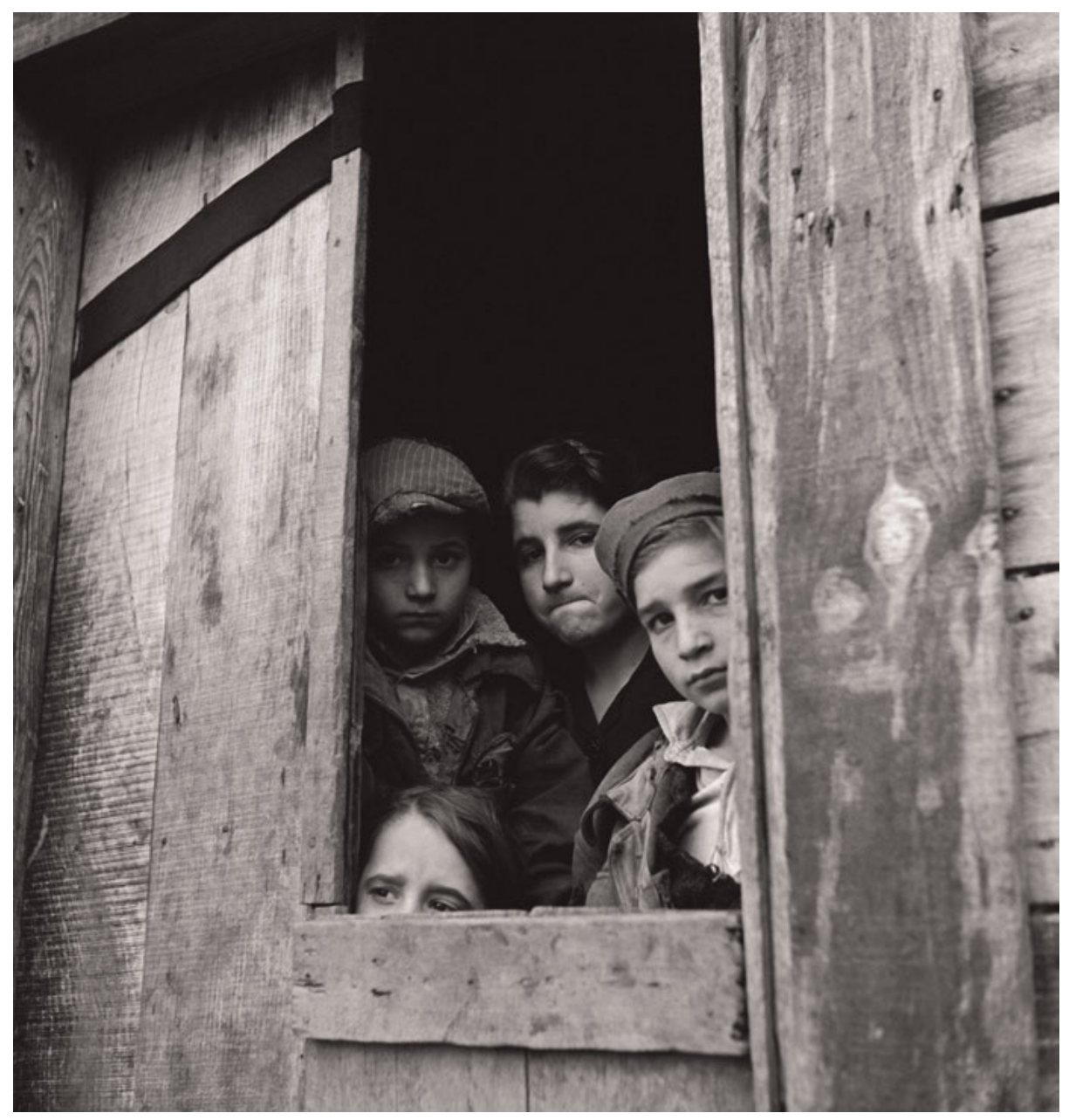

Fig. 1.29 


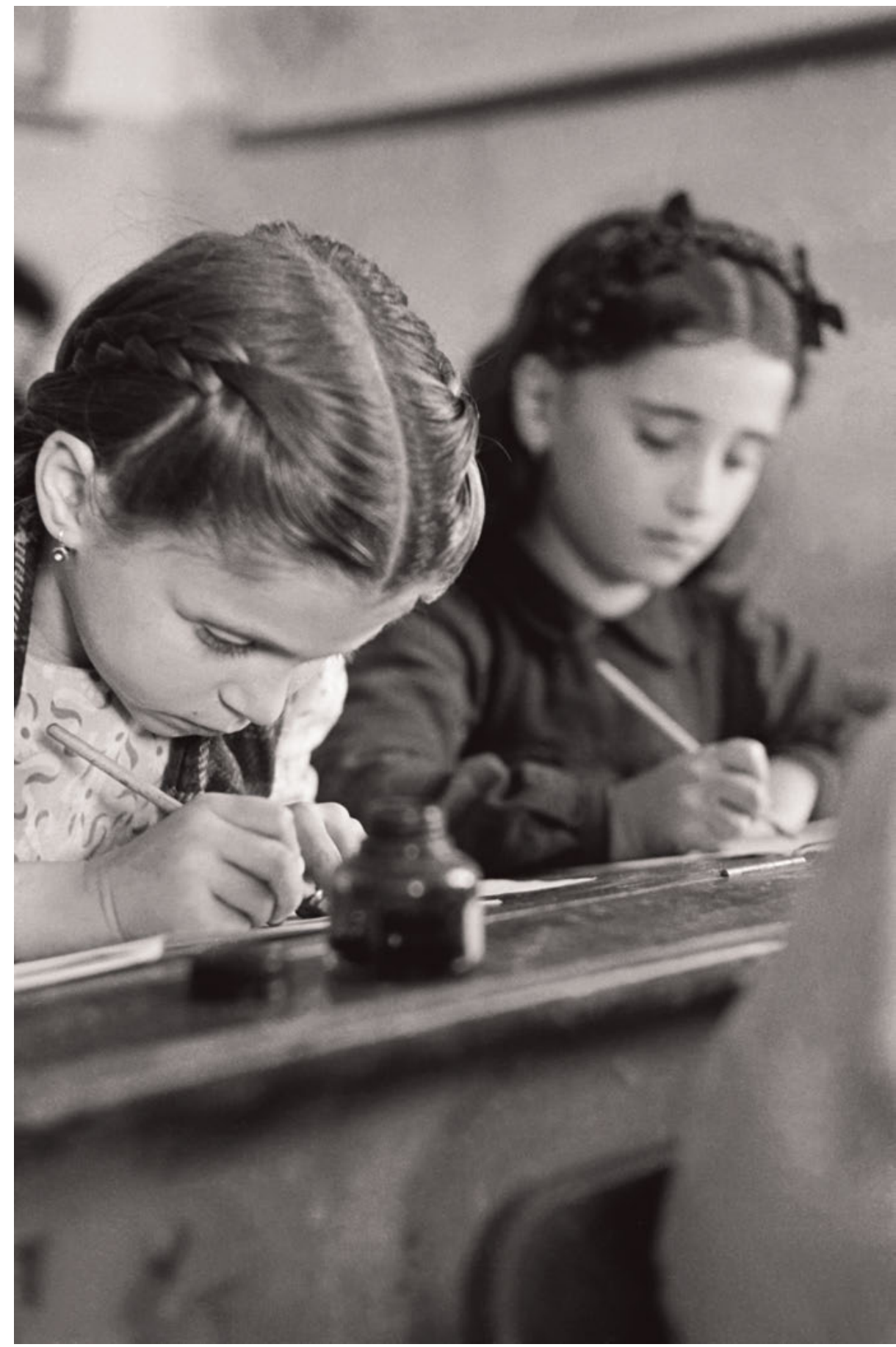

Fig. 1.30 